\title{
Stakeholders' Interests and Perceptions of Bioeconomy Monitoring Using a Sustainable Development Goal Framework
}

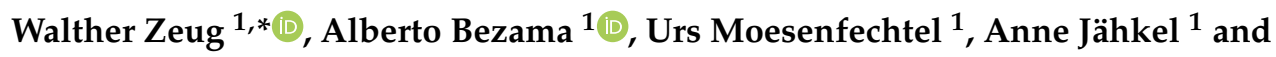 \\ Daniela Thrän ${ }^{1,2}$ (D) \\ 1 Department of Bioenergy, Helmholtz-Centre for Environmental Research (UFZ), 04318 Leipzig, Germany; \\ alberto.bezama@ufz.de (A.B.); urs.moesenfechtel@ufz.de (U.M.); anne.jaehkel@ufz.de (A.J.); \\ daniela.thraen@ufz.de (D.T.) \\ 2 Bioenergy Systems Department, Deutsches Biomasseforschungszentrum (DBFZ), 04318 Leipzig, Germany \\ * Correspondence: walther.zeug@ufz.de; Tel.: +49-341-235-4775
}

Received: 28 January 2019; Accepted: 6 March 2019; Published: 13 March 2019

\begin{abstract}
The bioeconomy as an industrial metabolism based on renewable resources is characterized by, not intrinsic, but rather potential benefits for global sustainability, depending on many factors and actors. Hence, an appropriate systematic monitoring of its development is vital and complexly linked to Sustainable Development Goals (SDGs) as well as diverse stakeholder expectations. To structure a framework of the important aspects of such a monitoring system, we conducted a series of stakeholder workshops to assess the relevance of SDGs for the bioeconomy. Our results show how the complexities of these issues are perceived by 64 stakeholders, indicating significant commonalities and differences among six SDGs, including specific interests, perceptions, and, in some cases, counterintuitive and contradictory issues. Eventually, the idea of a bioeconomy is a question of the perception of ends and means of a societal transformation toward holistic sustainability. Global implications like trade-offs, hunger, poverty, and inequalities are aspects of high relevance for monitoring of bioeconomy regions in which they actually do not seem to be substantial.
\end{abstract}

Keywords: bioeconomy; sustainability; sustainability assessment; monitoring; stakeholders; stakeholder participation; SDGs; holistic sustainability

\section{Introduction}

Sustainable development has been and remains a challenge for policymakers and the scientific community, as the definition of sustainability and the strategies for how to actually foster it still remain ambiguous [1], even though it has mostly become a collective global value of governments, science, nongovernmental organizations (NGOs), and civil society actors [2]. Needless to say, it is not yet possible to ensure a sustainable future since there are no certain global pathways for guaranteed sustainable development. As one considerable option to achieve sustainable development, in line with the Communique of the Global Bioeconomy Summit 2015 [3] bioeconomy (BE) can be understood as "the knowledge-based production and utilization of biological resources, innovative biological processes and principles to sustainably provide goods and services across all economic sectors" [4]. We follow this existing definition, even though sustainability is not an intrinsic characteristic but rather a promising potential of BE. However, there is still no unified definition of bioeconomy [5], because there is a whole range of stakeholders with diverse interests and perceptions. The vast majority of $\mathrm{BE}$ and sustainability related publications see conditional benefits but many others have a perspective of tentative criticism of $\mathrm{BE}$, when it comes to ecological and social sustainability or even state a 
disadvantageous impact $[6,7]$. For only a few publications mainly focusing on policies, sustainability is an inherent characteristic [6,7]. Three ideal types of BE visions have been identified in the broad scientific field but are mainly influenced by a technical perspective: (a) a biotechnology vision, (b) a bioresource vision, and (c) a bioecology vision [8]. These visions can be differentiated by dominant aims and objectives (economic growth for $\mathrm{a}$ and $\mathrm{b}$, job creation for $\mathrm{a}$, sustainability for $\mathrm{b}$ and $\mathrm{c}$ ); values created by BE (commercialization of research and technology for $a$, valorisation of bioresources for $b$, integrated production and high-quality products for c); drivers and mediators of innovation (research and development for $a$ and $b$, optimization of resources and land use for $b$ and $c$, agroecological practices and ethics for $\mathrm{c}$ ); and spatial focus (global clusters/central regions for $\mathrm{a}, \mathrm{rural} /$ peripheral regions for $\mathrm{b}$ and c) [8]. Furthermore, the diversity of BE concepts is represented in media discussions by several policy narratives partly similar to the named visions: biotechnology-centred $\mathrm{BE}$, resource-centred $\mathrm{BE}$, agroecological BE, BE as skilfulness, and climate change-centred BE [9].

\subsection{Bioeconomy Strategies and Policy}

Meanwhile, more than 50 countries worldwide have created BE-related policy strategies. However, just a few of them, such as the EU and Germany, have established specific and integrated BE strategies and action plans $[4,10,11]$ or institutions like the German BE Council. Nonetheless, the number of these endeavours has increased about 30\% since 2015 [12,13]. Most of these strategies mainly embrace the challenge of enabling biobased transformation, and only a few try to address potential risks and goal conflicts politically [14]. As a consequence, they address environmental and social challenges only to a lesser extent. Instead, many name vague interrelationships between economic, ecological, and social issues and mainly reflect an economic perspective on topics such as biotechnology, eco-efficiency, competitiveness, innovation, reaching or retaining a leading world position, growth in economic output, and (re-)establishing a next-generation industry at large $[1,5,10,11,15,16]$. Within the EU's BE strategy, the substitution of fossil carbon by renewable materials plays a big role in key industrial sectors such as chemicals and pharmaceuticals [11], which illustrates the potential in addition to the still very important energy production [17] and primary sectors in rural regions [18,19]. Many strategies highlight the contribution of BE to the circular economy and lately also to the improvement of food quality, alternative food resources, and high-tech sectors [4]. Moreover, the global dimensions and interconnections of a present and future BE are rarely addressed, and international collaborations play a minor role in these national rather than international strategies [4]. These are major shortcomings, since the vast majority of European countries also have not yet achieved Paris Agreement goals [20] and ecological as well as social risks and chances [7,21-23] result from an intensified and increased use of biobased resources, especially the shift of risks to other countries through imports and global market effects [24,25]. However, it should be the goal of a global BE to meet several big societal challenges [26] and to address a series of SDGs [27].

The updated BE strategy of the European Commission in 2018 is a step forward by aligning the strategy to maximize its contribution to the SDGs (in particular SDGs 2, 7, 8, 9, 11, 12,13,14,15) as well as the Paris Agreement [28]. Similar intentions could be implicitly found in 2010 in the first German Bioeconomy Strategy, in which five thematic fields of action were defined: "(i) global food security, (ii) sustainable agricultural production, (iii) healthy and safe foods, (iv) the industrial application of renewable resources, and (v) the increasing use of biomass-based energy" [29]. Complex and interdependent challenges on a national and international level need holistic and systematic perspectives and solutions for structural societal change [29]. Thus, a gradual change from biotechnology-centred visions to transformation-centred visions can be observed [30]. However, while BE can be seen as an emerging area of policy in Europe and Germany, specific and coherent legislation is still missing, as well as an effective, globally coordinated governance framework. Comprehensive monitoring and assessment approaches are seen as prerequisites to implementing legislation and governance frameworks on a national and international level [14,31]. 


\subsection{SDGs as a Normative Framework for the Bioeconomy}

The SDGs are considered to be the most appropriate global framework of goals for holistic sustainable development available, due to their rudimentary democratic character, wide recognition, and internationally comparable indicator framework [32-34]. For these reasons, they are increasingly becoming an overarching topic in BE strategies, policies, and action plans $[4,35]$. Putting forward such a goal system is a normative political challenge, beyond descriptive and empirical science, and is determining the controversial understanding and interpretation of sustainability [2,36], leading to some characteristics of the SDGs as (i) mainly containing elements of holistic sustainable development but presented as separate and not fully integrated [34]; (ii) implicitly interdependent, with complex synergies, trade-offs, and contradictions also depending on regions [37]; and (iii) goals and targets combining policy ends with means without proposing a hierarchy [38].

Previous research $[2,27]$ has outlined 11 out of 17 SDGs that are potentially highly relevant to a developing global BE (see Figure 1).

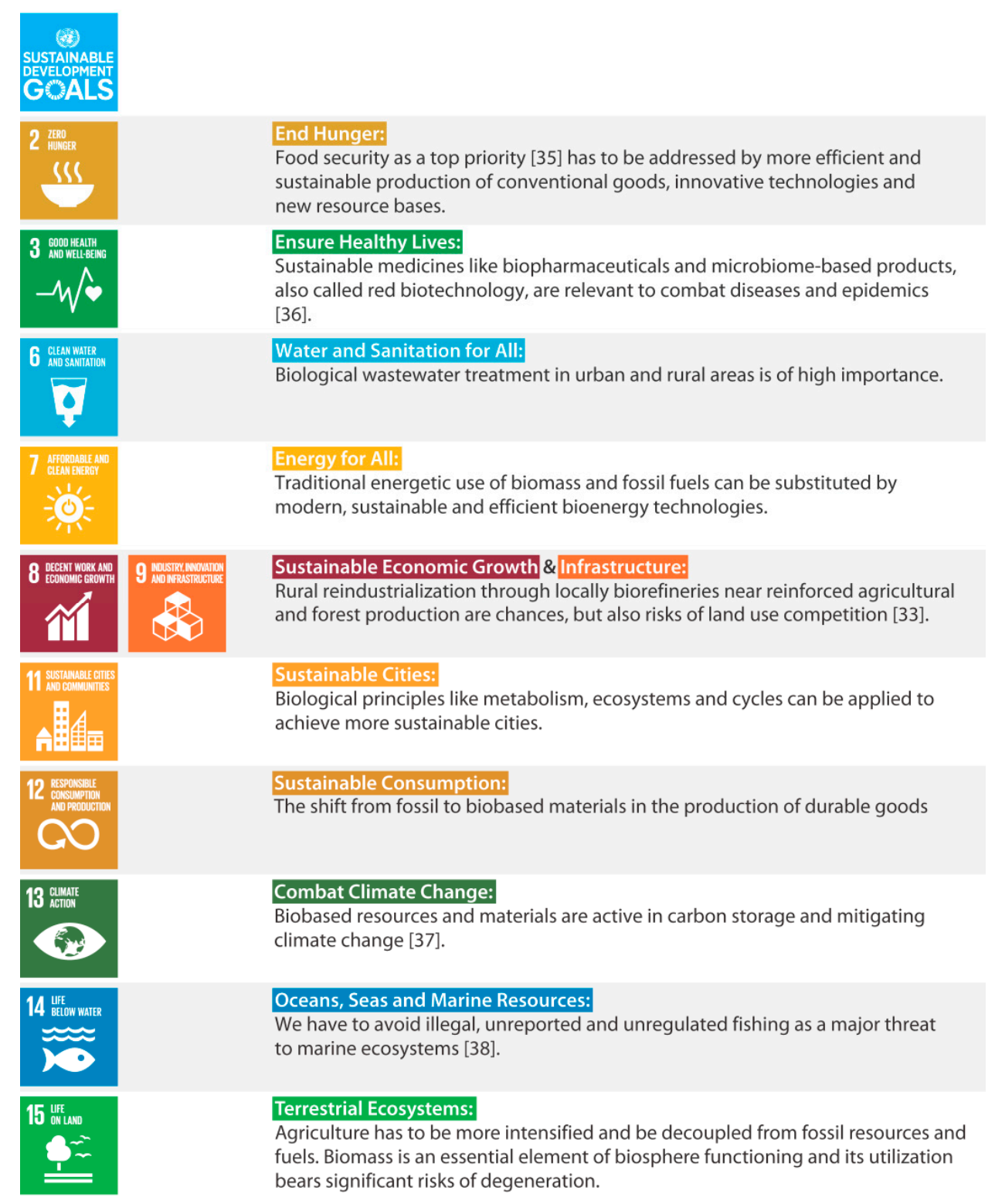

Figure 1. Sustainable development goals (SDGs) potentially highly relevant to a developing global bioeconomy (adapted from [2,27,37,39-42]). 
The diverse and rapidly developing field of new biotechnologies has the potential to address a series of SDGs in the energy and chemical sectors by substituting fossil materials; in the health care sector with new drugs, vaccines, and diagnostics; and in the primary sector by increasing food supplies and conserving natural resources [43]. When it comes to their implementation by measures, which should be in a simultaneous and not sequential manner [44], policymakers still lack tools and evidence to identify interdependencies and balance or to prioritize the most important issues [29,37,45]. Besides, there is a risk of reversing achievements by poor governance, escalating conflicts, and insecurity [46].

\subsection{What Gets Measured Can Get Managed}

Because of all these complex risks and chances, we should consciously evaluate and discuss potential options such as bioeconomy based on evidence, to achieve more sustainability before and during integration into policy, economy, and society. Hence, monitoring BE development and sustainability is vital and reasonable but no internationally agreed methodology exists and the framework conditions of such are not trivial due to diverse notions of what to actually monitor, especially when it comes to nontechnical aspects such as socioeconomics connected with visions and narratives.

The first contributions from science toward implementation can be to develop scientifically robust tools with defined indicators in order to help operationalize the SDGs on a global, national, and regional scale: to identify urgent challenges, to measure and manage progress, to assess and evaluate BE-supporting policies [31], and to fill data gaps in order to begin a process of data-driven and evidence-based implementation as well as follow-up $[38,47,48]$. Ideally, the analysis and interpretation of such measurements should be done by independent government-backed organizations within a global collaboration and according to international standards [49]. An increasing number of national strategies acknowledge the necessity of establishing complex BE monitoring systems [15]. Although defined and applied measurements of progress and sustainability are fundamental [16], they remain a major challenge [15] due to insufficient concepts, methods, and data. Thus far, for urgent use in political governance, there are no holistic, indicator-based, intersectoral or holistic monitoring systems available and quantitative assessments of how bioeconomy addresses the SDGs do not exist [29]. The purpose of $\mathrm{BE}$ monitoring is not just to show whether it is big or small but above all to understand its development and driving forces, and it should ultimately be about well-being-related outcomes [31]. Furthermore, it is also about understanding the relationships between different BE sectors (e.g., between material and energy streams) and at least the effects and potential impacts on society, economy, and nature as well as on their relationships. Short-term results can be adaptations of national and international policies and strategies, like the lacking environmental policy by the EU [10], setting global standards for meaningful certification [27], and delivering valid information to stakeholders such as NGOs and economic actors. Recently launched projects on an EU-wide scale, such as BioMonitor [50], BioSAM [51], and Sat-BEE [52], are moving on a EU-wide scale move in this promising direction.

Regarding this context, necessities and requirements of a smart monitoring system for assessing the sustainability of German BE must derive key criteria, indicators, and models from an integrated and holistic modelling approach. Several national statistical authorities and the Inter-Agency and Expert Group (IAEG) on SDGs [32] have drawn up comprehensive indicators or indicator sets for each subgoal so that suitable indicators for all SDG subgoals can be specified. However, the SDGs and their individual subgoals represent a general global political agenda and cannot be applied directly to $\mathrm{BE}$; they serve more to identify the normative aspects of BE monitoring than already constituting the monitoring framework itself. So far, such a comprehensive monitoring system fulfilling all the named criteria does not exist on any national scale, and Systematic Monitoring and Modelling of the BE (SYMOBIO), of which our study is a part [53], will be the first of its kind. Developing an appropriate monitoring framework is a challenge, because it has to be general in order to cover all relevant topics but also detailed in order to identify specific hotspots of general interest [54]. Due to 
the limited extent of the monitoring and its framework, the topics, drivers, and hotspots need to be selected and weighted, especially when it comes to the global dimensions of BE.

\subsection{Stakeholder Participation: A Necessity Rather Than a Burden}

In that regard, the insights and results from systematic stakeholder participation from the beginning can play an important role in addressing persistent societal problems in a credible, transparent, and multi-perspective way [35,47], as well as enable innovations [55]. Public decision making on sustainability is characterized by uncertainty, different values and interests, communities in dispute, as well as urgency [56-58], so that holistic approaches have included multiple fields of knowledge and perspectives of different stakeholders [59,60]. Most of the policy strategy developments in $\mathrm{BE}$ have already adopted a more or less participatory approach by stakeholder conferences, workshops and surveys [4], and private-public partnerships to encourage successful market integration [15]. Poor coherence between decision makers, scientists, and stakeholders was assessed to be at the origin of regulatory failures [61,62], and biotechnology was the subject of controversial public debates, making societal acceptance an enabling factor [63]. Basing BE policy on a broad societal debate should be a democratic imperative, and NGOs, as important public-opinion formers, have to participate [64]. Thus, the new European Bioeconomy Strategy explicitly calls for strategic and systematic approaches to bringing all stakeholders together in an attempt at policy coherence [28]. Therefore, researchers, initiatives, NGOs, and market actors have to be linked more closely with multilateral policy processes and intergovernmental discussions $[12,27,34,44]$, far beyond the traditional "triple helix" concepts (public sector, academia, business) or "fig leaf" participation, and should be mobilized by a common vision of a sustainable BE system. Otherwise, stakeholders with specific interests may dominate these developments and not necessarily contribute to the public good [6].

Previous studies on stakeholders in the context of the bioeconomy pursued completely different goals and scopes [35], were too general for our context [26,65], and/or used other stakeholder categories and attributes [26,65] and/or used other stakeholder-categories and attributes [66,67]. From an organizational point of view, Future Earth's Knowledge-Action Networks [68] set a good and ambitious example by initiating a growing number of locally implemented and globally networked collaborative frameworks of researchers and practitioners in both public and private sectors and civil society. Such an approach has the potential not only to provide a knowledge base for short-term democratic agendas of incentives and measures toward a potentially sustainable BE but also to actually put them into practice. So, shortcomings and insufficiencies of policy strategies can be overcome, risks and conflicts can be minimized, and difficult choices can be made to, at least practically, implement the SDGs simultaneously $[69,70]$. Science should contribute to these smart policies by providing a fundamental and integrated knowledge base of synergies, trade-offs, obstacles, and ways to combine these goals, identifying high-priority objectives and investigating questions that society defines as important [2,12].

\subsection{Present Knowledge Gaps and Objectives of This Research}

In a nutshell, as the main causes of several far-reaching effects impeding the potential sustainable development of $\mathrm{BE}$, we see the different interests and perceptions of sustainable development in general and of BE specifically among stakeholders. This manifests as a missing common definition, diverse and partly opposing visions and narratives, and insufficient governance frameworks. Holistic and extensive monitoring systems of the social, ecological, and economic effects of BE at an intersectoral level are in demand as the first step to address these issues. But the complexity of sustainability and economic systems like BE already generates too much information and normative conflicts for limited working groups to identify the most relevant aspects. This leads us back to the main causes. Stakeholder participation is therefore the most appropriate means to identify the key objectives in the first place. As a framework to grasp potential objectives, the SDGs offer a globally recognized 
general holistic goal system with some indicators and related comprehensive debates and are already implemented in most sustainability strategies and policies.

Accordingly, the general objective of this study is to capture, map, and analyse the societal interests and perceptions of the most relevant stakeholder groups of BE in Germany empirically by means of the SDGs. In reflecting upon their sometimes contradictory interests by the relevance of the SDGs, we want to provide indications for identification of key objectives and potential indicators and a basis for necessary weightings for the monitoring of BE. Additionally, insights into underlying perceptions can clarify the constellation of visions and narratives. The developed scientific tools could support evidence-based decision making in short-term governance, long-term political strategies, public and media discussions, and business processes to successfully implement a coherent vision of a BE pathway as a transformation addressing several big societal challenges.

\section{Methods}

Stakeholder perceptions and expectations regarding the effect of BE in SDGs in Germany were collected in a workshop series held in Berlin in October 2017. Research on practices or methods of stakeholder participation concerning BE or comparable issues or objectives is nascent (see $[26,35,65-67]$ ) but is led by different objectives and specific methodologies. Stakeholder analysis should explore configurations of sustainability issues like the bioeconomy from multiple or at least different, perspectives [71] and deliver critical reflections on social preferences without forcing consensus [59]. The chosen method of stakeholder participation should therefore provide an introduction to the topic; be able to identify potential and relevant stakeholders, their interests, perceptions, and priorities in relation to sustainability issues; and identify shared problem perceptions, and at least create a basis for a monitoring-framework for the German bioeconomy [59]. For our methodical framework we used established general approaches of stakeholder participation in terms of sustainability, in this case social multicriteria evaluation (SMCE) [59,71-74]. This method entails the following steps [59,72,73]: (i) identify and classify relevant stakeholders; (ii) define the problem; (iii) create alternatives and define evaluation criteria; (iv) assign values to criteria in a multicriteria impact matrix; (v) select a multicriteria evaluation method; (vi) assess social actors' preferences, values, and weights; (vii) apply the model through a mathematical aggregation procedure; and (viii) conduct social analysis and discuss the results to check the robustness of the analysis. We oriented our methodology in line with these steps and established methods but we did not follow a set of formal axioms; and rather, we composed the right methods for the right problem [73].

\subsection{Identifying and Bringing Together a Spectrum of Relevant Stakeholders}

We divided the workshops into three parts, held on different days, according to the stakeholder groups identified [75]: science, business, and society. To include a total set of stakeholders with the aspiration of representing all relevant stakeholders of German BE, we looked up the participants of important BE events in Germany from 2011 to 2017. Out of this, we identified 400 persons and the organizations they were assigned to. We selected and invited 200 of them to our workshops in such a manner that every organization was represented without personnel redundancies. The actual participants of our workshops were those persons or their stand-ins who responded our invitation, a total of 64 . According to the role, objective or interest of their organizations, we classified them into one of our stakeholder groups. Relevant nongovernmental organizations were represented by 6 major environmental organizations; 6 important developmental aid, food, and agriculture associations; 1 journalist; and 2 foundations. Those 15 stakeholders were classified as the society stakeholder group and represented the main relevant actors of NGOs when it comes to discussions on BE in Germany. The business stakeholder group comprised 9 associations from the biochemical, bioenergy, agricultural, and manufacturing industry sector; 5 working BE companies; $4 \mathrm{BE}$ consulting agencies; and 3 other associations, such as certifiers, for a total of 21. Thereby, the most important BE branches, clusters, and representatives of different commercial interests and fields of action could participate. The science 
stakeholder group consisted of 28 national and non-profit research institutes with explicit engagement in BE research topics, among them 13 universities. This wide and well-networked research community on $\mathrm{BE}$, which covers technological, ecological, economic, and societal issues of an established and developing $\mathrm{BE}$ with global interdependencies, was able to represent interdisciplinary expertise on all potentially relevant BE-related issues.

To ensure the quality of our method and the results, it was very important that all perspectives of the different stakeholders were presented at the workshops and that not only professionally organized groups but also social actors, participated [73], which we achieved. As a shortcoming, such classification into groups is only of limited accuracy, since the groups and the stakeholders could only be roughly defined. But it has decisive analytical and practical advantages. On the one hand, the perceptions of reality and the expectations of monitoring can be polarized but without forcing consensus, and fundamental societal conflicts of interest can be modelled. For those debates, monitoring can provide a scientific basis for decision making and formation of opinions. On the other hand, the potential for conflict in the stakeholder workshop process was reduced, resulting in greater productivity and consistency in the groups as well as more precise evaluation.

\subsection{Identification of Interests and Perceptions in Relation to the Problem Being Addressed and Indication of Relative Priorities}

In each workshop, we introduced the participants to the problem via a short presentation on the current situation and challenges of the bioeconomy, the problems, and envisaged steps for the development of a monitoring methodology of the German BE (see introduction). Basically, we explained the objective of their participation in this process, which was to provide opinions, from their perspective, on what is relevant in a monitoring system with the desired characteristics. We explicitly stated that this question should be thought of independently from how to measure it via indicators, since the creation of a monitoring framework at this stage should not be compromised by detailed challenges of the indicator-based measuring itself. The quality of monitoring, modelling, and other concepts that reflect reality or the system was also essentially dependent on how far all relevant aspects of perceptions of this reality were at least taken into account. To reduce the complexity in multicriteria evaluation (MCE), the virtually infinite information space has to be reduced to a limited set of narratives, expectations, and goals [59].

Now the task for the participants was to classify the SDG subgoals according to their relevance to $\mathrm{BE}$ monitoring in the given relevance categories (must be, may be or should not be part of national $\mathrm{BE}$ monitoring). In order to initiate the discussion process within a stakeholder group, to gain an even more differentiated picture of expectations and perceptions, and to reduce the complexity of the SDGs, the stakeholder groups were again divided into several smaller working groups (consisting of 4 persons on average), each of which had to categorize a specific part of the overall SDG subgoals. Thereby we lowered the risk that powerful stakeholders would influence the whole stakeholder group [72] and force consensus. Which part of the SDG subgoals a working group categorized was random and not determined by seeming expertise. We explained to the participants that specific political goal formulation of the SDG subgoal should not be of importance per se but only represents the abstract subject that was connoted by the goals and may be important to BE and its monitoring. Therefore, we asked the stakeholders to arrange the different subgoals into sections of relevance classes: the topic of the SDG subgoal must be, may be or should not be part of BE monitoring in Germany. We explicitly chose an ordinal variable here, since the character of variables is crucial for the fundamental issue of compensability [73]. The classification of each topic was discussed within the small working group under the supervision and assistance by one of our team members. Subsequently, all working groups were able to assess and comment on the categorization of the other groups via sticky notes in a feedback matrix according to attribute more relevance, less relevance, questions, and new ideas.

This option of deliberation is particularly important, because preferences and priorities can change and be formed through the discussion process. We followed ideas of deliberative and discursive 
democracy rather than simply aggregating individual preferences and assuming that they were fixed $[59,76,77]$. We were thus able to document the stakeholder workshops in this process and in the collection of all working groups by noting key points of discussion. We explicitly encouraged the participants to leave the SDG setting and name their own subject areas, which also outlined very concrete, stakeholder-specific questions. This method is only applicable if the stakeholders can come together in person with a sufficient amount of time, which is a potential shortcoming when these resources are scarcer. Moderators have to follow the discussions within these smaller working groups carefully to avoid dominant individuals forcing consensus.

\subsection{Scoring, Aggregation, and Robustness}

After each workshop, we transferred the categorized SDG subgoals and related feedback to a spreadsheet matrix for quantification (see Supplementary Material). The use of a relevance classification with ordinal variables originates "non-compensatory aggregation procedures and gives the weights the meaning of importance-coefficients [78-80]." As a consequence, the respective relevant weights cannot be understood as trade-offs or as compensatory between different issues [59,73] in a national monitoring system of BE. This is especially important in this case, since the SDGs should be seen and handled as a whole, and to avoid misunderstanding of a potential compensatory character related to sustainability issues. Otherwise we would implicitly assume that, for example, environmental impacts could compensate hunger, which is obviously not true even if there is a complex relationship between them.

The ordinal variable values of relevance (must/may/not) were rescaled to dimensionless ordinal variable scores of 3.0 to 1.0 for further processing, aggregation, and visualization (must: 3.0; may: 2.0; not: 1.0). Some of the SDG subgoals (subgoals 1.b, 6.5, 17.18, 10.2, 12.c, 8.10) were considered by some stakeholder groups as not at all applicable to monitoring or their meaning could not be deduced, and they got a value of 0.0. To incorporate the important role of discussions between working groups into the results, we operationalized them by adjusting their values if there were one or more items of feedback of more or less relevance attributed. For each given item of feedback, the related score of the SDG subgoal was increased (more relevance) or decreased (less relevance) by an adjustment value of 0.2. Since the ordinal scale reached from 3.0 to 1.0 and every stakeholder group was made up, on average, of 5 working groups (which means the given ordinal score can be theoretically increased or decreased up to a maximum of 0.8 ), a sensitivity analysis on this adjustment value was conducted to ensure robustness. In the chosen configuration, we got adjusted scores from 0.0 to 3.4. If the adjustment values would have been higher than 0.2 , in some cases the group feedback would have distorted the results too much and scores would have become negative. If they would have been lower than 0.2 , the results would have been too insensitive to feedback. We qualitatively appraised this configuration as an adequate compromise between methodical robustness efficiency and overall comprehensibility to conduct it as a feasible workshop with so many participants and within a limited time.

The adjusted scores that emerged from each stakeholder group for each subgoal were then collated. By a consistent equal weighting of all stakeholder groups, the scores of one group for the SDG main goal were calculated by simple linear aggregation of the average scores of the corresponding subgoals (see Figure 2). Likewise, for every SDG subgoal, an average score of all scores given by the 3 stakeholder groups was calculated. Since there is no meaning behind a differentiation of relevance below an ordinal score of 1.0 ("not" category) but values between 0.0 and 1.0 existed, we treated them in the subsequent rescaling as an ordinal score of 1.0. By using trivial transformation and normalization (cf. [73], Equation (23.7)), we scaled the ordinal scores from 1.0 to 3.4 to a scale of 0.0 (1.0) to 10.0 (3.4). The only purpose of this rescaling was to have a more intuitive and better reading and presentation of the results, and only these scores were subsequently used. 

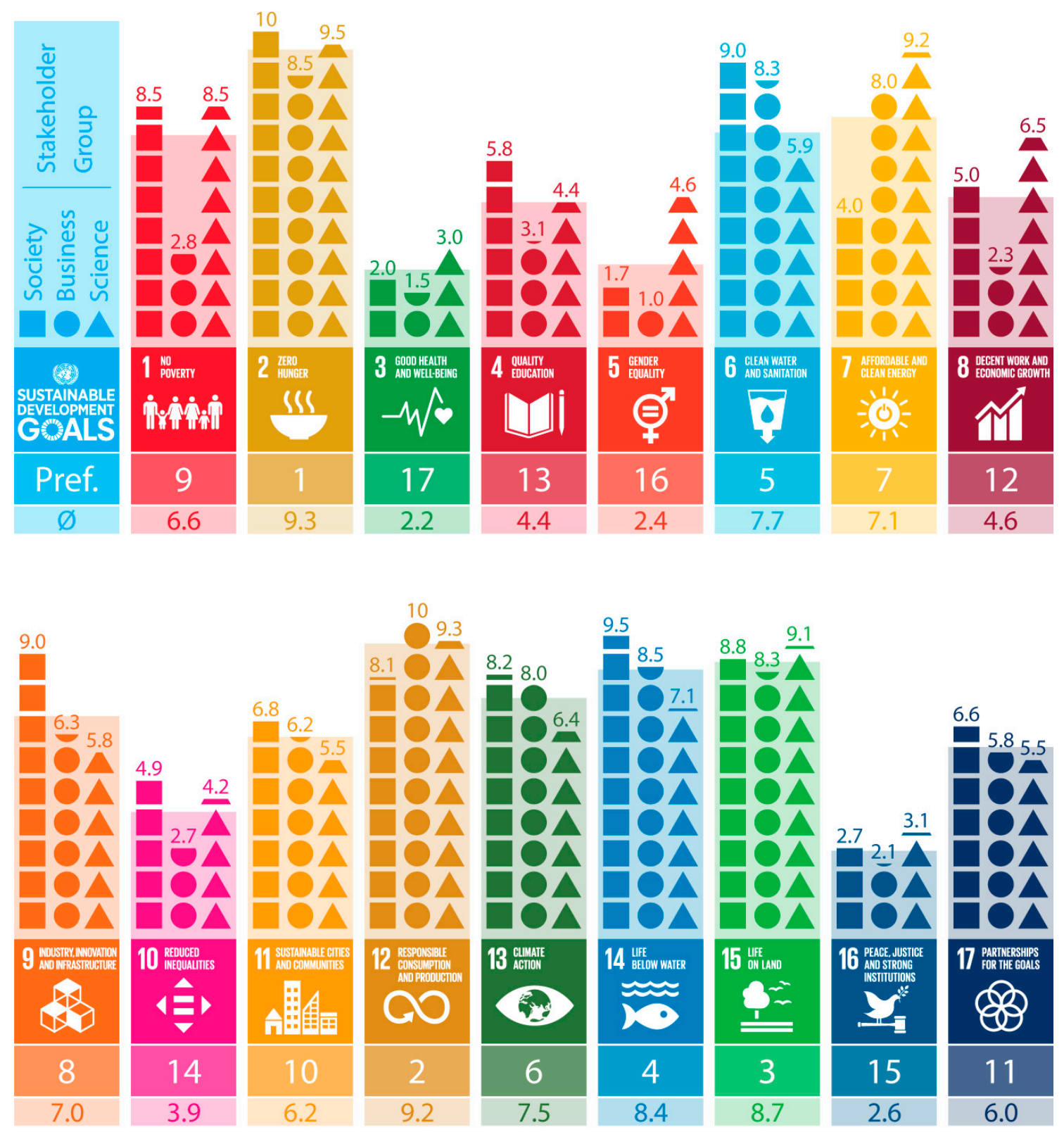

Figure 2. Analysis of German stakeholder -group perspectives on Sustainable Development Goals regarding bioeconomy. Relevance of SDGs based on relevance of corresponding subgoals given by stakeholder groups. Order of preference is given by mean values of relevance ( $\varnothing$ ) of an SDG given by all stakeholder groups. However, SDGs cannot be put into hierarchical order because they represent a complex and interlinked means-end continuum of socioeconomic relationships.

This aggregation procedure met the main requirements: all SDGs were treated in general as equally important and specifically were weighted by importance coefficients; all stakeholders were treated as equally important; and the aggregation and allocation of subgoals to main goals followed the legitimized system of the SDGs. The chosen approach is a purely qualitative method and assessment even if ordinal variables were rescaled as numerical scores for better processing and presentation. In this case, basic mathematical operations were conducted or average values were calculated. However, they did not necessarily meet all mathematical assumptions and requirements or produce precise results but were used for the purpose of presentation and visualization. Consequently, the data and results have no sufficient quantitative characteristics for statistical analysis. However, for future research and the application of such methods, more relevance classes and scales could be chosen, such 
as Likert scales, if this is feasible. This would avoid several scores of different subjects having the same value, which was the case in our study. Improving this would lead to a better resolution of aggregated scores, clearer rankings, and more options for further statistical analysis. Furthermore, the participants would be able to assign significantly more importance to aspects that are relevant from their point of view, for example, food security.

\subsection{Using Input from Stakeholders to Evaluate the Understanding of a Problem and Discuss the Results}

Based on social choice theory [81], this method of deliberative and discussed preferences of members of society and their decisions is supposed to reflect the convergence of collective preference [66]. Assuming this, the results from the stakeholder groups and the general aggregation are able to reflect the appropriate relevance of a group. The top third of the SDG subgoals, up to a score of 6.66, which respectively rank 48th, we consider as highly relevant for monitoring (i.e., "must" category). In the middle third, at scores of 3.33 to 6.66, ranking 67th to 113th, we see all SDG subgoals and topics as optional and nice to have (i.e., "may" category). From rank 113 to 169, with normalized scores of 3.33 to 0.00 , the aspects of sustainability with little to no relevance (i.e., "not" category) for $\mathrm{BE}$ in Germany are distributed. These scores are the aggregate scores of all stakeholder groups for each subgoal.

Nevertheless, it is necessary to provide the complete ranking of all aspects and not exclude or just select some alternatives a priori [72]. It was discussed that these results of scaled societal preferences could be used in a later stage of monitoring development to set up the weightings of the utilized parameters. However, the elicitation of weights should not be used in the further context of political evaluation but rather ethical and political principles [72], and thus those weights are limited for the presented application in quantitative monitoring. Our scaled results offer the first important insights into constellations of such preferences. However, just as important are the documented discussions, which enable us to interpret and give a first understanding of these constellations and which interests and perceptions are behind them. Since we assess no common method of multivariate statistics applicable to our data in a scientifically robust manner, our analyses have a qualitative character.

\section{Results: Reflecting Interests and Perceptions}

In order to avoid lengthy tables, we have included the scores of all stakeholder groups for each subgoal in Tables A1-A3 for detailed consideration. In summary, the stakeholders classified the subgoals so that 56 of them should not be part (score $<3.33$, "not" category), and 47 of them may be part (score 3.33 to 6.66 , "may" category) of this monitoring. Another 66 subgoals were classified as so relevant that the issues they represent must be part of monitoring German BE (score $\geq 6.66$, "must" category).

For presentation of the results, the subgoals are grouped as corresponding SDGs. First, from the "not" category (see Tables 1 and A1), 36 subgoals had little relevance (score 0.00 to 3.33), which means that at least one working group of a stakeholder group assigned them any relevance by their own classification or gave feedback on them. The remaining 20 subgoals (score $=0.00$ ) had no relevance at all for any stakeholder group or working group. Most of the subgoals from SDG 3, 5, 16, and 10 are part of this class, even though some of them are much more relevant (e.g., "reduce pollution of air/water/soil, health protection" (score(3.9) = 8.61); "reduction of bribery/corruption" (score(16.6) = 7.22); "improvement of representation/participation of developing countries" (score $(10.6)=7.50)$ ).

Secondly, the same amount or more than half of the subgoals from SDG 6, 9, and 4 may be part of future monitoring. This class of 47 SDG subgoals (27\% of all subgoals, see Tables 1 and A2) may be part of a monitoring system and includes subgoals with scores between 3.33 and 6.66. Of these, $59.6 \%$ scored higher than 5.00, therefore tend to be in the "must" category and should be carefully evaluated before being neglected. 
Table 1. From the stakeholder perspective, relative frequencies of SDG subgoals in a class of relevance in \% (ordered according to the SDGs, whose subgoals occur mainly in the most relevant classes).

\begin{tabular}{|c|c|c|c|c|}
\hline \multirow[t]{2}{*}{$\begin{array}{l}\text { SDG } \\
\text { Code }\end{array}$} & \multirow[t]{2}{*}{ SDG } & \multicolumn{3}{|c|}{$\begin{array}{l}\% \text { of Sub-Goals in } \\
\text { Class of Relevance }\end{array}$} \\
\hline & & Must & May & Not \\
\hline 15 & $\begin{array}{l}\text { Protect, restore and promote sustainable use of terrestrial ecosystems, } \\
\text { sustainably manage forests, combat desertification, and halt and reverse } \\
\text { land degradation and halt biodiversity loss }\end{array}$ & 83.3 & 16.7 & 0.0 \\
\hline 2 & $\begin{array}{l}\text { End hunger, achieve food security and improved nutrition and promote } \\
\text { sustainable agriculture }\end{array}$ & 75.0 & 25.0 & 0.0 \\
\hline 12 & Ensure sustainable consumption and production patterns & 72.7 & 27.3 & 0.0 \\
\hline 14 & $\begin{array}{l}\text { Conserve and sustainably use the oceans, seas and marine resources for } \\
\text { sustainable development }\end{array}$ & 70.0 & 30.0 & 0.0 \\
\hline 7 & Ensure access to affordable, reliable, sustainable and modern energy for all & 60.0 & 40.0 & 0.0 \\
\hline 13 & Take urgent action to combat climate change and its impacts* & 60.0 & 40.0 & 0.0 \\
\hline 6 & $\begin{array}{l}\text { Ensure availability and sustainable management of water and sanitation } \\
\text { for all }\end{array}$ & 50.0 & 50.0 & 0.0 \\
\hline 11 & Make cities and human settlements inclusive, safe, resilient and sustainable & 50.0 & 20.0 & 30.0 \\
\hline 1 & End poverty in all its forms everywhere & 42.9 & 28.6 & 28.6 \\
\hline 9 & $\begin{array}{l}\text { Build resilient infrastructure, promote inclusive and sustainable } \\
\text { industrialization and foster innovation }\end{array}$ & 25.0 & 62.5 & 12.5 \\
\hline 17 & $\begin{array}{l}\text { Strengthen the means of implementation and revitalize the global } \\
\text { partnership for sustainable development }\end{array}$ & 42.1 & 21.1 & 36.8 \\
\hline 8 & $\begin{array}{l}\text { Promote sustained, inclusive and sustainable economic growth, full and } \\
\text { productive employment and decent work for all }\end{array}$ & 16.7 & 41.7 & 41.7 \\
\hline 4 & $\begin{array}{l}\text { Ensure inclusive and equitable quality education and promote lifelong } \\
\text { learning opportunities for all }\end{array}$ & 10.0 & 50.0 & 40.0 \\
\hline 10 & Reduce inequality within and among countries & 20.0 & 30.0 & 50.0 \\
\hline 16 & $\begin{array}{l}\text { Promote peaceful and inclusive societies for sustainable development, } \\
\text { provide access to justice for all and build effective, accountable and } \\
\text { inclusive institutions at all levels }\end{array}$ & 8.3 & 8.3 & 83.3 \\
\hline 5 & Achieve gender equality and empower all women and girls & 0.0 & 22.2 & 77.8 \\
\hline 3 & Ensure healthy lives and promote well-being for all at all ages & 7.7 & 0.0 & 92.3 \\
\hline
\end{tabular}

Finally, the widest class represents $39 \%$ of all subgoals that must be part of a monitoring system from a stakeholder perspective (see Tables 1 and A3). A majority of subgoals from SDG 15, 14, and 13 were assessed as "must haves" in monitoring and stand for basic environmental aspects. At least as relevant are many subgoals of SDG 2, 12, 7, 6, and 2, representing food security, sustainable agriculture, production and consumption patterns, and sustainable infrastructure in cities and rural areas.

Taking a closer look at the 10 most relevant SDG subgoals according to their average scores by overall stakeholder groups shows a set of very different aspects with relatively close scores of relevance (see Table 2). The reduction of waste and urban pollution (subgoals 11.6 and 12.5), the protection of ecosystems (6.6 and 15.9), food security (2.1 and 2.2), research on sustainability (12.a) and governance aspects $(13.2,17.14$, and 12.2) combine a series of different SDGs as well as high relevance by all stakeholder groups. A high average score results from high relevance by all stakeholders and indicates consensus regarding their importance.

Next, regarding stakeholder-specific scores of individual subgoals and the differences between them, on average they are most significant in the "may" category, followed by the "not" category, and subgoals in the "must" category are the least controversial (see Table 3). Of 169 subgoals, the science stakeholder group gave an average score of 5.10, the business stakeholder group 4.42, and the society group 5.37. This shows a tendency of stakeholders in the science and society group to consider more subgoals as relevant for monitoring than stakeholders in the business group. Related to all subgoals, there is no clear evidence of a general higher convergence of the scores of science and business, science and society or business and society compared to the others. However, a detailed view of the 10 most controversial subgoals shows that 5 of them are societal aspects: ending the discrimination of women 
(subgoals 5.1 and 4.1) and issues of supporting developing countries (8.a, 9.5, and 10.a). Strikingly, 4 of them were seen as very relevant by the science and society stakeholder groups, whereas business stakeholders neglected them.

Table 2. From stakeholder perspective: top 10 most relevant SDG subgoals for monitoring of bioeconomy. shgSci, stakeholder group science; shgBus, stakeholder group business; shgSoc, stakeholder group society; aggr., aggregated results of all stakeholder groups, mean values.

\begin{tabular}{|c|c|c|c|c|c|c|}
\hline \multirow{2}{*}{$\begin{array}{l}\text { SDG } \\
\text { Code }\end{array}$} & \multirow{2}{*}{ SDG Sub-Goal } & \multicolumn{4}{|c|}{ Score $\mathbf{0 . 0 - 1 0 . 0}$} & \multirow{2}{*}{ Rank aggr. } \\
\hline & & shgSci & shgBus & shgSoc & aggr. & \\
\hline 11.6 & $\begin{array}{c}\text { Reduce urban environmental impacts, air } \\
\text { quality, waste treatment }\end{array}$ & 9.17 & 9.17 & 9.17 & 9.17 & 1 \\
\hline 12.5 & $\begin{array}{l}\text { Reduction of waste generation (prevention, } \\
\text { reduction, recycling and reuse) }\end{array}$ & 9.17 & 9.17 & 9.17 & 9.17 & 1 \\
\hline 2.1 & Food access, food security & 9.17 & 9.17 & 8.33 & 8.89 & 3 \\
\hline 13.2 & $\begin{array}{l}\text { Climate protection measures, politics, } \\
\text { strategies, planning }\end{array}$ & 10.00 & 8.33 & 8.33 & 8.89 & 3 \\
\hline 6.6 & Protection of all water-related ecosystems & 9.17 & 8.33 & 9.17 & 8.89 & 5 \\
\hline 12.2 & $\begin{array}{c}\text { Sustainable management of natural } \\
\text { resources }\end{array}$ & 8.33 & 9.17 & 9.17 & 8.89 & 5 \\
\hline 12.a & $\begin{array}{l}\text { Strengthen research on sustainable } \\
\text { production/consumption }\end{array}$ & 9.17 & 8.33 & 9.17 & 8.89 & 5 \\
\hline 15.9 & $\begin{array}{l}\text { Aichi biodiversity targets, ecosystem and } \\
\text { biodiversity values }\end{array}$ & 9.17 & 8.33 & 9.17 & 8.89 & 5 \\
\hline 17.14 & $\begin{array}{c}\text { Policy coherence in sustainable } \\
\text { development }\end{array}$ & 9.17 & 8.33 & 9.17 & 8.89 & 5 \\
\hline 2.2 & End malnutrition, food security & 8.33 & 9.17 & 8.33 & 8.61 & 10 \\
\hline
\end{tabular}

Table 3. From stakeholder perspective: top 10 most controversial SDG subgoals for monitoring of bioeconomy between stakeholder groups. shgSci, stakeholder group science; shgBus, stakeholder group business; shgSoc, stakeholder group society; aggr., aggregated results of all stakeholder groups, mean values; $\varnothing$ Diff., average difference between scores.

\begin{tabular}{|c|c|c|c|c|c|c|}
\hline \multirow{2}{*}{$\begin{array}{l}\text { SDG } \\
\text { Code }\end{array}$} & \multirow{2}{*}{ SDG Sub-Goal } & \multicolumn{4}{|c|}{ Score $\mathbf{0 . 0 - 1 0 . 0}$} & \multirow{2}{*}{$\varnothing$ Diff } \\
\hline & & shgSci & shgBus & shgSoc & aggr. & \\
\hline 5.1 & Eliminate discrimination against women & 9.17 & 0.00 & 8.33 & 5.83 & 6.11 \\
\hline 7.3 & Double rate of increase of energy efficiency & 9.17 & 8.33 & 0.00 & 5.83 & 6.11 \\
\hline 8.5 & $\begin{array}{l}\text { Resource efficiency in } \\
\text { consumption/production }\end{array}$ & 9.17 & 0.00 & 8.33 & 5.83 & 6.11 \\
\hline 8.a & $\begin{array}{l}\text { Support developing countries/technical } \\
\text { assistance }\end{array}$ & 8.33 & 0.00 & 9.17 & 5.83 & 6.11 \\
\hline 9.5 & $\begin{array}{c}\text { Strengthen/promote scientific research in } \\
\text { developing countries }\end{array}$ & 8.33 & 0.00 & 9.17 & 5.83 & 6.11 \\
\hline 12.c & Abolish fossil fuel subsidies & 9.17 & 8.33 & 0.00 & 5.83 & 6.11 \\
\hline 12.7 & Sustainable public procurement & 5.00 & 10.00 & 0.83 & 5.28 & 6.11 \\
\hline 8.7 & $\begin{array}{l}\text { Increase share of youth employment, } \\
\text { education and vocational training }\end{array}$ & 9.17 & 5.00 & 0.00 & 4.72 & 6.11 \\
\hline 10.a & Justice, treatment of developing countries & 5.00 & 0.00 & 9.17 & 4.72 & 6.11 \\
\hline 4.1 & $\begin{array}{l}\text { Equal access / free education from } \\
\text { elementary schools on (girls/boys) }\end{array}$ & 0.83 & 0.00 & 9.17 & 3.33 & 6.11 \\
\hline
\end{tabular}

Concerning feedbacks to attribute more or less relevance given by the different working groups within a stakeholder-group: 6 working groups of the stakeholder group science attributed 52 times more and 3 times less relevance to sub-goals as their colleagues; 5 working groups of business attributed 22 times more and 4 times less relevance; and in the case of 4 working groups of the stakeholder group society 28 feedbacks that gave more relevance were recorded. 
Furthermore, a first glance at the aggregated scores of the 17 SDGs based on the scores of their corresponding subgoals (see Figure 2) shows the same common strong and widespread relevance for all environmental aspects (SDGs 13-15) without significant differences between stakeholder groups. Following a preference order calculated by the mean values of the relevance of an SDG given by all stakeholder groups, ending hunger (SDG 2), responsible consumption and production (12), all environmental aspects (13-15), infrastructure (9), energy (7), and drinking water supply (5) are the most relevant SDGs for monitoring of the German BE. These are followed by global partnerships, sustainable cities, decent work, inequalities, and education (SDGs 17, 11, 8, 4, and 10).

Peace, gender equality, and health (SDGs 16, 5, 3) appear to be topics of less relevance. However, against the background of these orders of preference and relevance, we have to emphasize that the SDGs cannot be put into a hierarchical order, since they represent a complex and interlinked means-end continuum of socioeconomic relationships. The loss of information in this representation lies in subgoals whose relevance has been assessed significantly differently from the other subgoals of the same key goal. For example, subgoal 11.6 (urban pollution, air quality, waste treatment) is assigned much higher relevance (score $(11.6)=9.17)$ than SDG 11 in general $($ score $(11)=6.17)$.

An interesting aspect from the results shown in Figure 2 regarding the different stakeholder groups, besides the expected similarities (SDGs 15, 16, 17, 11, 2, 3) and significant differences $(1,7$, $8,5,9,6)$, is that the strongest divergence by far emerges in the perception of ending poverty (1). No clear evidence can be found for a general convergence of relevance between specific stakeholder groups over all 17 SDGs, as well as for all 169 subgoals. But again, when it comes to mainly social aspects of sustainability (SDGs 1, 2, 3, 4, 5, 8, 10,16), a clear qualitative correlation between the science and society stakeholder groups becomes visible: these stakeholder groups assign significantly more relevance to social aspects than the business stakeholder group. For all other SDGs, the differences in relevance between stakeholder groups do not have a significant qualitative correlation.

From recording the discussion process at our stakeholder workshops, a series of further, partly fundamental questions and positions appeared, some in line with the additionally proposed aspects above. Stakeholders in the science group emphasized that not only national but necessarily global effects of a German, European, and transnational BE must be taken into account in order to identify trade-offs, leakage effects, and refire and backfire effects and avoid them in the future. Business stakeholders were particularly interested in the international regulatory framework for BE activities such as market access, commodity restrictions, trade restrictions, subsidies, and financing options. In addition, price indicators of products and raw materials as well as political-economic instruments, for example, internalization of external costs or physical material flows, were relevant for them. These issues stand in general for information necessary for strategic economic management decisions in BE. For stakeholders in the society group, the main question was to what extent BE merely represents a substitution of the resource base of capitalism or is an actual socioeconomic change toward a more sustainable world. Identifying international land use changes and effects on food prices, and thus the nutritional situation of a growing population as well as the ecological effects, is also a central objective and conflict of interest.

Overall, the results indicate that topics of ecology from marine pollution to environmental education are as significantly relevant as food security and the associated political development and economic framework. Thus, from the perspective of all stakeholders, a series of aspects representing the social, ecological, and economic dimensions of sustainability as well as enabling factors of policy-making have to be considered in a monitoring system. Relatively irrelevant are the subjective visions of discontiguous topics, such as drug abuse but also increased GDP growth.

\section{Discussion: Means, Ends, Perceptions, and Contradictions}

Our empiric results, aggregated into main goals, mainly corroborate the findings of previous research and discussions on BE-related SDGs. Many of the SDGs that experts have defined as important (see Figure 1) are also highly relevant for most our stakeholders, such as ending hunger (SDG 2), water 
and sanitation (6), energy (7), sustainable growth and infrastructure (8 and 9), sustainable cities (11), sustainable consumption (12), climate change (13), and terrestrial and oceanic ecology (14 and 15). However, stakeholders in general see less relevance of health issues (SDG 3) but consider ending poverty (1), global partnerships (17), and education (4) as far more important. We assume that the reasons for this are the popular, general scientific, political, and societal discourse dimensions of BE (fuel vs. food, green cities and green growth) in case of similarities. Two convergent issues, ensuring food security and ending malnutrition (subgoals 2.1 and 2.2), are among the most relevant subgoals from all stakeholder perspectives, emphasizing that biomass should be primarily used for nutritional purposes. On the other hand, the potential of biopharmaceutical technologies and products in the health sector still seems to be an unpopular topic of discourse of specialists in this field, since research and development of medication and access to them (subgoals 3.b and 3.8) are classified as irrelevant. Better communication of BE high-tech potentials (e.g., biopharmaceuticals) and their transparent development would also help in this regard and contribute to faster implementation.

Taking a closer look at the SDG subgoals, it is quite surprising that reduction of urban environmental impact and waste (subgoals 11.6 and 12.5), ranking at number 1, may not seem to be the most popular BE-associated topic (see Table 2). Even though waste is a feedstock with significant potential for the bioeconomy, not only in highly industrialized economies [82]. Of course, there are strong connections between urban development and climate change [83], and green cities and sustainable urbanization play a certain role in the BE discourse [4]. But we assume this significance could also be strengthened by viral societal and media discussions, as urban air pollution was in Germany at the time of our workshops, where some stakeholders made remarks on such topics as biofuels, waste, and urban farming. These are well-known lessons learned from the fuel versus food debate $[84,85]$ and show the strong influence of sometimes volatile topics of medial narratives affecting policy process and public opinion [9]. This does not mean that these topics are therefore less relevant. The high relevance of most ecological aspects and sustainable consumption and production is in line with the results of general surveys on the perceptions of BE. In addition, it also became clear how important the governance frameworks and policy coherence (subgoal 17.14) appear among all stakeholders, showing the relevance of enabling factors and interdisciplinary aspects that are quite uncommon in monitoring systems.

On the one hand, our results show what may seem to be counterintuitive in terms of monitoring in one of the most industrialized nations in the world: the dimensions of sustainability are far beyond local ecological concerns, and the awareness of global environmental effects, international trade-offs, and big societal challenges such as hunger, poverty, and inequality is rising. In particular, a growing German or European BE will depend on imports [25], so national monitoring has to implement these aspects. Nevertheless, when a monitoring framework of regionally quite diverse BEs is developed on a global scale or with another regional focus [14], in our case subordinate aspects like health (SDG 3), education (4), gender equality (5), economic growth and jobs (8), and peace and justice (17) can be much more relevant aspirations. Even within the EU, the socioeconomic effects of biobased activities are found to be highly heterogeneous [51].

On the other hand, our results show how much the relevance of different topics is a question of interests and perceptions depending on stakeholder groups, showing the need to take different BE visions and narratives into account beyond scientific discussions (cf. [8]). Our results show rather strong particular interests by business stakeholders in contrast to more universal interests by society and science stakeholders. This became particularly clear in most of the social aspects, and a closer look at the most and least contentious SDG subgoals (see Table A2) supports this assessment, as well as the most significant difference in relevance between stakeholder groups: the assessment of ending poverty (SDG 1), to which business stakeholders assign far less relevance than the others. However, a bias that those stakeholders are not at all interested in societal challenges is contrasted by their interest in ending hunger. Even though there are similarities in the relevance of some SDGs as assessed by different stakeholders, all stakeholder perspectives are motivated by specific means of achieving 
specific ends based on values that can, of course, overlap and change in an ongoing progress or regress. These different means, ends, and values seem to be the guiding factors in what we have understood as conflicting interests and perceptions, and they are context-specific. Furthermore, they seem to be the main reason for a lacking common definition of BE. It has been assumed that all stakeholders should have an incentive to internalize external effects [31,86], which remains to be fundamentally questioned $[87,88]$. Moreover, it is a question of the visions and narratives: when BE is superficially understood as a potential socioeconomic transition toward holistic sustainability, ending poverty, global partnerships, and education play more vital roles; when BE is only a substitution of primary resources, the changes in socioeconomic dimensions are abstract in contrast to environmental effects. The successive changes of the European and German BE strategies toward transformation-centred visions underline the first case. Addressing this complexity and interlinkages, future policy strategies and legislation in Germany should be strongly interministerial, coordinated by a common strategy and appropriate measures at a federal and regional level [29].

One intrinsic quality of the SDGs is to implicitly combine ends and means. In the emphasized case, purchasing power (ending poverty, SDG 1) is a necessary condition for the purpose of satisfying needs (ending hunger, SDG 2), at least within the current widespread economic system. Regarding this, the characteristic for the discussion process was the relevance of individual subgoals determined by how and to what extent stakeholders rate these as more or less related to BE. Such subjective perception of the mediating relationships of certain aspects of the (bio-)economy with ecological and societal effects seems to be the crucial cause, not only for the relevance of topics of monitoring but also for the interpretation of sustainability in general $[34,89]$. These relationships cannot be reduced to simple, one-directional causalities but rather have to be understood as a whole [90,91]. Inherent contradictions between socioeconomic development and ecological sustainability, which manifest as conflicts and trade-offs between partly incompatible SDGs [92,93], exemplify this and remain a global governance challenge [14].

Comparing our results with the mentioned BE visions [8] and narratives [9] is possible only to a very limited extent, since the objectives, methodologies, and criteria are too different and aspects overlap. However, no vision or narrative can be clearly allocated to a specific stakeholder group, and vice versa. In our case, we cannot define clear images of "heroes," "villains," or "victims" [9]. While the qualitative and quantified interests and perceptions show an affinity of the business stakeholder group to biotechnology-centred visions and narratives of the society stakeholder group, mainly ecological and social ones, the science stakeholder group shares interests with all visions and narratives.

We have shown that it is crucial for a monitoring system to be able to inform and measure the aspects of and provide information about current and future risks and chances resulting from a developing bioeconomy. Regarding our main objective, to identify the most important aspects of monitoring BE from a stakeholder perspective, the subgoals of the "must" and "may" categories should be a substantial basis for the development of a national monitoring framework for BE in Germany (see Tables A2 and A3). Consequently, besides the more common ecological and economic aspects, food security, sustainable production, infrastructure, and final consumption (SDGs 2, 8, 11, 12) have been integrated explicitly as key objectives in "Conceptualization of an Indicator System for Assessing the Sustainability of the Bioeconomy" [54] in the context of SYMOBIO. Furthermore, the science stakeholder group in particular followed our hint to leave the SDG setting and proposed a series of issues specific to the discussions around BE that were not part of the SDGs but should nevertheless be implemented (e.g., new primary biomass resources, national and global potentials; advanced indicators to measure leakage, rebound, reduction, and substitution effects; awareness, acceptance, and significance regarding BE; BE-specific energy consumption, emissions, footprints, and animal welfare; political evaluation of $\mathrm{BE}$ and indicators for policy strategies). When it comes to indices formed through aggregation, the relevance order and scores can be particularly important for necessary weightings. 


\section{Conclusions}

We propose a comprehensive set of 66 aspects that must be part and 47 that may be part of a monitoring system. It is evident that sustainability has to be approached as a holistic and complex subject, because "social," "ecological," and "economic" aspects are at least equally important. In addition, institutional, political, and societal enabling factors are part of this. We emphasize that ambitious assessment and monitoring cover a variety of aspects, especially issues of vital societal discussion. Taking into account only certain issues, as too often in the past, can cause shortened analyses and possibly false scientific, political and media conclusions. Being sensitive to this can lead to a scientific knowledge base for these debates and their outcomes, as well as may avoid existential crises and discursive dead ends like the fuel versus food nexus and debate. Therefore, we have proposed indicators that all stakeholders consider important but also those that are valued differently in terms of their relevance.

The primary and obvious limitation of this research is the inclusion of only German stakeholders and the focus on monitoring the German bioeconomy. Not only international stakeholders play a role in highly interlinked national economies but the results are context-specific and only applicable in a limited and abstract manner to other regional contexts. Besides, in methodological terms, the way of collecting the relevance of aspects and aggregating can be improved by using more appropriate qualitative scales, such as Likert scales, and ultimately our setup of stakeholder groups has limited accuracy. Our results have a qualitative character and thus we did not conduct statistically sound quantitative analysis.

Future studies on stakeholder participation, interests, and perceptions should include international stakeholders and multiregional BEs. This is fundamental when implementing global governance frameworks, not only for BE. By increasing the number of stakeholders and methods of data collection, quantitative statistical analysis should be conducted as well as in-depth interviews to gain more solid insight into underlying interest, perceptions, and values. Those studies have to be aware of universal and particular interests of specific stakeholder groups. When it comes to developing further strategies to realize the SDGs by BE and implementing measures in legislation, governance frameworks, and practices based on evidence from monitoring [54], we also propose closer interactions with global institutions and structures like the Sustainable Development Solutions Network [46]. The continued pursuit of ambitious stakeholder participation can make a significant contribution to policy coherence and to avoiding regulatory failures in the future. By developing a monitoring framework oriented to addressing all stakeholders and their expectations as much as possible, benefits from the acceptance and usage of the monitoring, as well as bioeconomy concepts, are likely to be achieved.

Further basic research on societal relationships with nature can improve our understanding of these complex relationships [94,95]; however, global negotiation processes including all stakeholders will have to organize these relationships [68]. Following previous research and most stakeholders, $\mathrm{BE}$ should not just be considered as a substitution of the resource basis but rather as a societal and economic transformation toward more sustainable development $[1,30]$. Both a transition necessary to achieve sustainability and the already inevitable effects of being late at doing this will lead to significant political disruptions in the short and long term, so the need for democratic practices is urgent $[91,96]$. Monitoring can support such processes by providing an evidence base, necessary because holistic sustainability is not an intrinsic character of either BE or other economies. Beyond that and most importantly, we all need to argue for a narrative, means-end continuum, and vision of this transformation that is given by neither the SDGs nor the BE themselves. It would also be a significant step toward a common BE definition. 
Supplementary Materials: The following are available online at http:/ /www.mdpi.com/2071-1050/11/6/1511/ s1, Data and aggregation from the stakeholder workshops.

Author Contributions: D.T., U.M., A.J., and W.Z. prepared the workshops and carried out, supervised, and evaluated them. W.Z. did the data curation and general analysis as well as the conceptualization, writing, management, and submission of this research article. The manuscript has been edited by A.B. and D.T. and reviewed by all authors.

Funding: The work was financed primarily by the support of the Systematic Monitoring and Modelling of the BE (SYMOBIO) Project, funded by the German Federal Ministry of Education and Research (FZK: 031B0281B).

Acknowledgments: Figures 1 and 2 were illustrated by Björn Schinkel.

Conflicts of Interest: The authors declare no conflict of interest.

\section{Appendix A}

Table A1. From stakeholder perspective: 56 SDG subgoals with little or no relevance to monitoring of German bioeconomy. shgSci, stakeholder group science; shgBus, stakeholder- group business; shgSoc, stakeholder group society; aggr.,. aggregated results of all stakeholder groups, mean values.

\begin{tabular}{|c|c|c|c|c|c|c|}
\hline \multirow{2}{*}{$\begin{array}{l}\text { SDG } \\
\text { Code }\end{array}$} & \multirow{2}{*}{ SDG Sub-Goal } & \multicolumn{4}{|c|}{ Score $\mathbf{0 . 0 - 1 0 . 0}$} & \multirow{2}{*}{ Rank aggr } \\
\hline & & shgSci & shgBus & shgSoc & aggr. & \\
\hline 4.4 & Increase number of adolescents/adults with apprenticeship & 0.83 & 4.17 & 4.17 & 3.06 & 114 \\
\hline 5.c & Gender equality/self-determination of women & 8.33 & 0.83 & 0.00 & 3.06 & 114 \\
\hline 8.6 & Productive full employment, decent work, pay equity & 0.83 & 4.17 & 4.17 & 3.06 & 114 \\
\hline 10.3 & $\begin{array}{c}\text { Equal opportunities, abolition of discriminatory } \\
\text { laws/policies/practices }\end{array}$ & 5.00 & 4.17 & 0.00 & 3.06 & 114 \\
\hline 16.10 & Legal identity & 8.33 & 0.83 & 0.00 & 3.06 & 114 \\
\hline 16.b & Non-discriminatory legislation & 4.17 & 5.00 & 0.00 & 3.06 & 114 \\
\hline 17.2 & Fair and multilateral trading systems & 5.00 & 4.17 & 0.00 & 3.06 & 114 \\
\hline 17.13 & Financial aid, development assistance & 0.83 & 4.17 & 4.17 & 3.06 & 114 \\
\hline 3.1 & Lower maternal mortality & 0.00 & 4.17 & 4.17 & 2.78 & 122 \\
\hline 3.2 & Reduction of deaths newborns/children $<5$ years & 0.83 & 3.33 & 4.17 & 2.78 & 122 \\
\hline 3.3 & Fighting AIDS, tuberculosis, malaria, etc. & 8.33 & 0.00 & 0.00 & 2.78 & 122 \\
\hline 3.8 & Access to health care/insurance, medicines, vaccines & 8.33 & 0.00 & 0.00 & 2.78 & 122 \\
\hline 3.d & Health risks, early detection & 8.33 & 0.00 & 0.00 & 2.78 & 122 \\
\hline 4.6 & Greatly reduce illiteracy worldwide & 0.00 & 0.00 & 8.33 & 2.78 & 122 \\
\hline 5.5 & Leadership positions/equal opportunities for women & 8.33 & 0.00 & 0.00 & 2.78 & 122 \\
\hline 8.1 & Per capita economic growth, GDP increase & 8.33 & 0.00 & 0.00 & 2.78 & 122 \\
\hline $9 . \mathrm{a}$ & Development aid for technology in developing countries & 0.00 & 0.00 & 8.33 & 2.78 & 122 \\
\hline 10.7 & Secure, responsible migration policy/mobility & 0.00 & 0.00 & 8.33 & 2.78 & 122 \\
\hline 16.7 & Transparent institutions & 0.00 & 0.00 & 8.33 & 2.78 & 122 \\
\hline 17.4 & Customs and quota-free market access & 4.17 & 0.00 & 4.17 & 2.78 & 122 \\
\hline 17.9 & $\begin{array}{l}\text { Building partnerships/exchange of experience (public, } \\
\text { private, civil society) }\end{array}$ & 4.17 & 0.00 & 4.17 & 2.78 & 122 \\
\hline 17.15 & Investment promotion & 8.33 & 0.00 & 0.00 & 2.78 & 122 \\
\hline 17.19 & Capacity building international cooperation & 0.00 & 0.00 & 8.33 & 2.78 & 122 \\
\hline $5 . \mathrm{b}$ & Use of basic technologies, self-determination of women & 0.00 & 3.33 & 4.17 & 2.50 & 137 \\
\hline 16.a & Capacity building in combating violence/terrorism/crime & 4.17 & 0.00 & 0.83 & 1.67 & 138 \\
\hline 3.5 & Strengthen prevention/treatment of drug abuse & 0.00 & 0.00 & 4.17 & 1.39 & 139 \\
\hline $8 . b$ & Global strategy on youth employment & 4.17 & 0.00 & 0.00 & 1.39 & 139 \\
\hline 10.c & Lower transaction costs of international home transfers & 4.17 & 0.00 & 0.00 & 1.39 & 139 \\
\hline 11.1 & Affordable housing & 0.00 & 0.00 & 4.17 & 1.39 & 139 \\
\hline 11.7 & Secure access to green areas/public space & 0.00 & 0.00 & 4.17 & 1.39 & 139 \\
\hline 16.5 & Reduction of financial and arms flows/organized crime & 0.83 & 3.33 & 0.00 & 1.39 & 139 \\
\hline 16.2 & Protect access to information/fundamental freedoms & 0.00 & 3.33 & 0.00 & 1.11 & 145 \\
\hline 10.4 & Political measures fiscal/wage policy/social protection & 0.83 & 0.00 & 1.67 & 0.83 & 146 \\
\hline 1.3 & Social protection systems and measures & 0.83 & 0.00 & 0.83 & 0.56 & 147 \\
\hline 16.3 & End abuse/exploitation of children & 0.00 & 0.00 & 0.83 & 0.28 & 148 \\
\hline 1.b & $\begin{array}{c}\text { Policy Frameworks for pro-poor and gender-sensitive } \\
\text { development strategies }\end{array}$ & 0.00 & 0.00 & 0.00 & 0.00 & 149 \\
\hline 3.4 & Reduce premature mortality (e.g., cardiovascular disease) & 0.00 & 0.00 & 0.00 & 0.00 & 149 \\
\hline 3.6 & Reduce traffic accidents & 0.00 & 0.00 & 0.00 & 0.00 & 149 \\
\hline
\end{tabular}


Table A1. Cont.

\begin{tabular}{|c|c|c|c|c|c|c|}
\hline \multirow{2}{*}{$\begin{array}{l}\text { SDG } \\
\text { Code }\end{array}$} & \multirow{2}{*}{ SDG Sub-Goal } & \multicolumn{4}{|c|}{ Score $\mathbf{0 . 0 - 1 0 . 0}$} & \multirow{2}{*}{ Rank aggr } \\
\hline & & shgSci & shgBus & shgSoc & aggr. & \\
\hline 3.7 & \multirow{2}{*}{$\begin{array}{c}\text { Strengthen sexual and reproductive health and education } \\
\text { Health care, education, tobacco control (according to WHO } \\
\text { agreement) }\end{array}$} & 0.00 & 0.00 & 0.00 & 0.00 & 149 \\
\hline 3.a & & 0.00 & 0.00 & 0.00 & 0.00 & 149 \\
\hline 3.b & \multirow{2}{*}{$\begin{array}{l}\text { Research and development of vaccines } \\
\text { Health financing, education and number of healthcare } \\
\text { professionals }\end{array}$} & 0.00 & 0.00 & 0.00 & 0.00 & 149 \\
\hline 3.c & & 0.00 & 0.00 & 0.00 & 0.00 & 149 \\
\hline 4.a & $\begin{array}{c}\text { Construction Educational Facilities/Safe Learning } \\
\text { Environment }\end{array}$ & 0.00 & 0.00 & 0.00 & 0.00 & 149 \\
\hline 4.c & Increase number of teacher training teachers & 0.00 & 0.00 & 0.00 & 0.00 & 149 \\
\hline 5.2 & Eliminate violence against women & 0.00 & 0.00 & 0.00 & 0.00 & 149 \\
\hline 5.3 & $\begin{array}{l}\text { End harmful practices for women (e.g., forced marriage, } \\
\text { genital mutilation) }\end{array}$ & 0.00 & 0.00 & 0.00 & 0.00 & 149 \\
\hline 5.4 & $\begin{array}{l}\text { Structural integration of unpaid caring and housework as a } \\
\text { service }\end{array}$ & 0.00 & 0.00 & 0.00 & 0.00 & 149 \\
\hline 5.6 & \multirow{2}{*}{$\begin{array}{l}\text { Access strengthen sexual and reproductive health } \\
\text { Worker rights, labour protection rights, promoting safe work } \\
\text { environment }\end{array}$} & 0.00 & 0.00 & 0.00 & 0.00 & 149 \\
\hline 8.9 & & 0.00 & 0.00 & 0.00 & 0.00 & 149 \\
\hline 8.10 & \multirow{3}{*}{$\begin{array}{c}\text { Promoting policies of sustainable tourism } \\
\text { Self-determination, political/social/economic inclusion } \\
\text { Reduce deaths/Economic losses due to environmental } \\
\text { disasters }\end{array}$} & 0.00 & 0.00 & 0.00 & 0.00 & 149 \\
\hline 10.2 & & 0.00 & 0.00 & 0.00 & 0.00 & 149 \\
\hline 11.5 & & 0.00 & 0.00 & 0.00 & 0.00 & 149 \\
\hline 16.1 & Reduce violence-related mortality & 0.00 & 0.00 & 0.00 & 0.00 & 149 \\
\hline 16.4 & Promoting the rule of law/access to justice & 0.00 & 0.00 & 0.00 & 0.00 & 149 \\
\hline 16.9 & \multirow{2}{*}{$\begin{array}{l}\text { Participation of developing countries in steering institutions } \\
\text { Capacity building technologies/innovation/research in } \\
\text { communications sector }\end{array}$} & 0.00 & 0.00 & 0.00 & 0.00 & 149 \\
\hline 17.18 & & 0.00 & 0.00 & 0.00 & 0.00 & 149 \\
\hline
\end{tabular}

Table A2. From stakeholder perspective: 47 SDG subgoals that may be part of monitoring German bioeconomy. shgSci, stakeholder group science; shgBus, stakeholder group business; shgSoc, stakeholder group society; aggr., aggregated results of all stakeholder groups, mean values.

\begin{tabular}{|c|c|c|c|c|c|c|}
\hline \multirow{2}{*}{$\begin{array}{l}\text { SDG } \\
\text { Code }\end{array}$} & \multirow{2}{*}{ SDG Sub-Goal } & \multicolumn{4}{|c|}{ Score $\mathbf{0 . 0 - 1 0 . 0}$} & \multirow{2}{*}{ Rank aggr } \\
\hline & & shgSci & shgBus & shgSoc & aggr. & \\
\hline 2.3 & Increase agricultural productivity, income (small producers) & 5.83 & 5.00 & 8.33 & 6.39 & 67 \\
\hline 1.5 & $\begin{array}{c}\text { Increase resistance of population against extreme climate } \\
\text { events }\end{array}$ & 8.33 & 1.67 & 8.33 & 6.11 & 68 \\
\hline 4.3 & Promote gender equality & 8.33 & 5.00 & 5.00 & 6.11 & 68 \\
\hline 5.1 & Eliminate discrimination against women & 9.17 & 0.00 & 8.33 & 5.83 & 70 \\
\hline 7.3 & Double rate of increase of energy efficiency & 9.17 & 8.33 & 0.00 & 5.83 & 70 \\
\hline 8.5 & Resource efficiency in consumption/production & 9.17 & 0.00 & 8.33 & 5.83 & 70 \\
\hline 8.a & Support developing countries/technical assistance & 8.33 & 0.00 & 9.17 & 5.83 & 70 \\
\hline 9.2 & Sustainable industrialization & 0.83 & 8.33 & 8.33 & 5.83 & 70 \\
\hline 9.5 & $\begin{array}{c}\text { Strengthen/promote scientific research in developing } \\
\text { countries }\end{array}$ & 8.33 & 0.00 & 9.17 & 5.83 & 70 \\
\hline 9.c & Access to information and communication technology & 8.33 & 8.33 & 0.83 & 5.83 & 70 \\
\hline 10.1 & Income growth & 8.33 & 0.83 & 8.33 & 5.83 & 70 \\
\hline 12.c & Abolish fossil fuel subsidies & 9.17 & 8.33 & 0.00 & 5.83 & 70 \\
\hline 14.2 & Sustainable management of coastal ecosystems & 5.00 & 4.17 & 8.33 & 5.83 & 70 \\
\hline 1.a & Financial support/development aid, eradication of poverty & 8.33 & 0.00 & 8.33 & 5.56 & 80 \\
\hline 4.5 & Gender disparities (parity indices) & 8.33 & 4.17 & 4.17 & 5.56 & 80 \\
\hline 6.5 & Integrated management of water resources & 0.00 & 8.33 & 8.33 & 5.56 & 80 \\
\hline $6 . b$ & Improvement of water management, sanitation & 4.17 & 8.33 & 4.17 & 5.56 & 80 \\
\hline 7.2 & Increase share of renewable energies, energy mix & 8.33 & 8.33 & 0.00 & 5.56 & 80 \\
\hline 9.1 & Resilient infrastructure & 8.33 & 0.00 & 8.33 & 5.56 & 80 \\
\hline $9 . \mathrm{b}$ & $\begin{array}{l}\text { Support local technology development in developing } \\
\text { countries }\end{array}$ & 0.00 & 8.33 & 8.33 & 5.56 & 80 \\
\hline 11.4 & Protection of world cultural and natural heritage & 0.83 & 7.50 & 8.33 & 5.56 & 80 \\
\hline 12.b & Monitoring sustainable tourism & 0.00 & 8.33 & 8.33 & 5.56 & 80 \\
\hline 14.6 & Prohibit fishing subsidies & 0.00 & 8.33 & 8.33 & 5.56 & 80 \\
\hline
\end{tabular}


Table A2. Cont.

\begin{tabular}{|c|c|c|c|c|c|c|}
\hline \multirow{2}{*}{$\begin{array}{l}\text { SDG } \\
\text { Code }\end{array}$} & \multirow{2}{*}{ SDG Sub-Goal } & \multicolumn{4}{|c|}{ Score $\mathbf{0 . 0 - 1 0 . 0}$} & \multirow{2}{*}{ Rank aggr } \\
\hline & & shgSci & shgBus & shgSoc & aggr. & \\
\hline 16.8 & Democratic decision-making & 4.17 & 4.17 & 8.33 & 5.56 & 80 \\
\hline 17.3 & Increase exports of developing countries & 4.17 & 8.33 & 4.17 & 5.56 & 80 \\
\hline 17.6 & Policy coherence in sustainable development & 4.17 & 8.33 & 4.17 & 5.56 & 80 \\
\hline 12.7 & Sustainable public procurement & 5.00 & 10.00 & 0.83 & 5.28 & 93 \\
\hline 8.8 & $\begin{array}{l}\text { Worker rights, abolition of forced labour/trafficking/child } \\
\text { labour }\end{array}$ & 5.83 & 0.83 & 8.33 & 5.00 & 94 \\
\hline 8.7 & $\begin{array}{l}\text { Increase share of youth employment, education and } \\
\text { vocational training }\end{array}$ & 9.17 & 5.00 & 0.00 & 4.72 & 95 \\
\hline 10.a & Justice, treatment of developing countries & 5.00 & 0.00 & 9.17 & 4.72 & 95 \\
\hline 2.b & $\begin{array}{c}\text { Trade restrictions, - prevent distortions, stop agricultural } \\
\text { export subsidies }\end{array}$ & 5.00 & 0.00 & 8.33 & 4.44 & 97 \\
\hline 6.2 & Sanitation/hygiene & 5.00 & 0.00 & 8.33 & 4.44 & 97 \\
\hline 11.2 & Infrastructure/traffic system & 5.00 & 4.17 & 4.17 & 4.44 & 97 \\
\hline 17.7 & Political scope regarding poverty elimination & 5.00 & 4.17 & 4.17 & 4.44 & 97 \\
\hline 13.3 & Education and awareness about climate protection & 4.17 & 8.33 & 0.83 & 4.44 & 101 \\
\hline 4.b & Increase number of scholarships & 8.33 & 4.17 & 0.00 & 4.17 & 102 \\
\hline 6.a & Capacity building for wastewater treatment/reprocessing & 0.00 & 4.17 & 8.33 & 4.17 & 102 \\
\hline 13.1 & Emergency plans & 4.17 & 0.00 & 8.33 & 4.17 & 102 \\
\hline $14 . b$ & $\begin{array}{l}\text { Conservation/sustainable use of oceans, convention on the } \\
\text { law of the sea }\end{array}$ & 4.17 & 0.00 & 8.33 & 4.17 & 102 \\
\hline 15.7 & Combat poaching/trade of protected plants & 4.17 & 0.00 & 8.33 & 4.17 & 102 \\
\hline 17.11 & Measurement of sustainable development & 0.00 & 4.17 & 8.33 & 4.17 & 102 \\
\hline 5.a & $\begin{array}{c}\text { Financial equality, legal framework for women (e.g., pension, } \\
\text { real estate) }\end{array}$ & 8.33 & 3.33 & 0.00 & 3.89 & 108 \\
\hline 15.c & Combating poaching/wildlife trade & 3.33 & 0.00 & 8.33 & 3.89 & 108 \\
\hline 4.1 & $\begin{array}{c}\text { Equal access/free education from elementary schools on } \\
\text { (girls/boys) }\end{array}$ & 0.83 & 0.00 & 9.17 & 3.33 & 110 \\
\hline 4.2 & $\begin{array}{l}\text { Equal access/free education from preschool/kindergarten on } \\
\text { (girls/boys) }\end{array}$ & 0.83 & 0.00 & 9.17 & 3.33 & 110 \\
\hline 10.5 & Regulation/supervision of global financial markets & 5.00 & 4.17 & 0.83 & 3.33 & 110 \\
\hline 8.3 & Econ. productivity increase through diversification & 1.67 & 0.00 & 8.33 & 3.33 & 113 \\
\hline
\end{tabular}

Table A3. From stakeholder perspective: 66 SDG subgoals that must be part of monitoring German bioeconomy. shgSci, stakeholder group science; shgBus, stakeholder group business; shgSoc, stakeholder group society; aggr., aggregated results of all stakeholder groups, mean values.

\begin{tabular}{|c|c|c|c|c|c|c|}
\hline \multirow{2}{*}{$\begin{array}{l}\text { SDG } \\
\text { Code }\end{array}$} & \multirow{2}{*}{ SDG Sub-Goal } & \multicolumn{4}{|c|}{ Score $\mathbf{0 . 0}-\mathbf{1 0 . 0}$} & \multirow{2}{*}{ Rank aggr } \\
\hline & & shgSci & shgBus & shgSoc & aggr. & \\
\hline 11.6 & $\begin{array}{c}\text { Reduce urban environmental impacts, air quality, waste } \\
\text { treatment }\end{array}$ & 9.17 & 9.17 & 9.17 & 9.17 & 1 \\
\hline 12.5 & $\begin{array}{c}\text { Reduction of waste generation (prevention, reduction, } \\
\text { recycling and reuse) }\end{array}$ & 9.17 & 9.17 & 9.17 & 9.17 & 1 \\
\hline 2.1 & Food access, food security & 9.17 & 9.17 & 8.33 & 8.89 & 3 \\
\hline 13.2 & Climate protection measures, politics, strategies, planning & 10.00 & 8.33 & 8.33 & 8.89 & 3 \\
\hline 6.6 & Protection of all water-related ecosystems & 9.17 & 8.33 & 9.17 & 8.89 & 5 \\
\hline 12.2 & Sustainable management of natural resources & 8.33 & 9.17 & 9.17 & 8.89 & 5 \\
\hline 12.a & Strengthen research on sustainable production/consumption & 9.17 & 8.33 & 9.17 & 8.89 & 5 \\
\hline 15.9 & Aichi biodiversity targets, ecosystem and biodiversity values & 9.17 & 8.33 & 9.17 & 8.89 & 5 \\
\hline 17.14 & Reduction of over-indebtedness/external debt & 9.17 & 8.33 & 9.17 & 8.89 & 5 \\
\hline 2.2 & End malnutrition, food security & 8.33 & 9.17 & 8.33 & 8.61 & 10 \\
\hline 2.4 & Sustainable systems in food production (resilience) & 9.17 & 8.33 & 8.33 & 8.61 & 10 \\
\hline 2.a & $\begin{array}{c}\text { Investment in rural infrastructure, agricultural research and } \\
\text { consulting }\end{array}$ & 9.17 & 8.33 & 8.33 & 8.61 & 10 \\
\hline 3.9 & Reduce pollution of air/water/ soil, health protection & 8.33 & 8.33 & 9.17 & 8.61 & 10 \\
\hline 4.7 & Education for sustainable development & 9.17 & 8.33 & 8.33 & 8.61 & 10 \\
\hline 6.1 & Access to affordable drinking water, food security & 8.33 & 9.17 & 8.33 & 8.61 & 10 \\
\hline 8.4 & Promoting decent work, innovation, creativity, SMEs & 9.17 & 8.33 & 8.33 & 8.61 & 10 \\
\hline
\end{tabular}


Table A3. Cont.

\begin{tabular}{|c|c|c|c|c|c|c|}
\hline \multirow{2}{*}{$\begin{array}{l}\text { SDG } \\
\text { Code }\end{array}$} & \multirow{2}{*}{ SDG Sub-Goal } & \multicolumn{4}{|c|}{ Score $\mathbf{0 . 0 - 1 0 . 0}$} & \multirow{2}{*}{ Rank aggr. } \\
\hline & & shgSci & shgBus & shgSoc & aggr. & \\
\hline 12.3 & Food waste/losses, post-harvest losses, resource efficiency & 9.17 & 8.33 & 8.33 & 8.61 & 10 \\
\hline 12.4 & Environmentally friendly handling of chemicals and waste & 9.17 & 8.33 & 8.33 & 8.61 & 10 \\
\hline 12.6 & Reporting on sustainability information & 8.33 & 9.17 & 8.33 & 8.61 & 10 \\
\hline 15.2 & Sustainable forest management/reforestation & 9.17 & 8.33 & 8.33 & 8.61 & 10 \\
\hline 15.a & Conservation, sustainable use, biodiversity, ecosystems & 8.33 & 8.33 & 9.17 & 8.61 & 10 \\
\hline 15.b & Forest conservation/reforestation & 9.17 & 8.33 & 8.33 & 8.61 & 10 \\
\hline 2.5 & Preserve genetic diversity of seeds/plants/animals & 8.33 & 8.33 & 8.33 & 8.33 & 23 \\
\hline 2.c & Stability food market, fluctuations of food prices, reserves & 8.33 & 8.33 & 8.33 & 8.33 & 23 \\
\hline 6.3 & $\begin{array}{c}\text { Increase water quality, pollution/chemicals, } \\
\text { sewage/reprocessing }\end{array}$ & 8.33 & 8.33 & 8.33 & 8.33 & 23 \\
\hline 9.4 & Sustainable renewal of industrial infrastructures & 8.33 & 8.33 & 8.33 & 8.33 & 23 \\
\hline 12.8 & $\begin{array}{c}\text { Information for consciousness about sustainable } \\
\text { development }\end{array}$ & 8.33 & 8.33 & 8.33 & 8.33 & 23 \\
\hline 14.1 & Reduce marine pollution, marine litter/nutrient pollution & 8.33 & 8.33 & 8.33 & 8.33 & 23 \\
\hline 14.4 & Overfishing/management plans & 8.33 & 8.33 & 8.33 & 8.33 & 23 \\
\hline 14.5 & Preserve coastal and marine areas & 8.33 & 8.33 & 8.33 & 8.33 & 23 \\
\hline 14.7 & Sustainable management of fisheries, aquaculture, tourism & 8.33 & 8.33 & 8.33 & 8.33 & 23 \\
\hline 15.5 & Protecting natural habitats, threatened species, biodiversity & 8.33 & 8.33 & 8.33 & 8.33 & 23 \\
\hline 17.1 & Mobilizing local resources, taxes and duties & 8.33 & 8.33 & 8.33 & 8.33 & 23 \\
\hline 17.10 & Capacity expansion in data collection & 8.33 & 8.33 & 8.33 & 8.33 & 23 \\
\hline 17.16 & North-south/south-south/triangular cooperation & 8.33 & 8.33 & 8.33 & 8.33 & 23 \\
\hline 11.a & $\begin{array}{l}\text { Regional development planning, linkage of urban and rural } \\
\text { areas }\end{array}$ & 10.00 & 4.17 & 9.17 & 7.78 & 36 \\
\hline 15.1 & $\begin{array}{c}\text { Preservation/sustainable use of terrestrial and inland } \\
\text { freshwater ecosystems }\end{array}$ & 5.00 & 8.33 & 9.17 & 7.50 & 37 \\
\hline 10.6 & $\begin{array}{l}\text { Improvement of representation/participation of developing } \\
\text { countries }\end{array}$ & 5.83 & 8.33 & 8.33 & 7.50 & 38 \\
\hline 11.3 & Sustainable urbanization & 8.33 & 9.17 & 5.00 & 7.50 & 38 \\
\hline 12.1 & Sustainable consumption and production patterns & 9.17 & 5.00 & 8.33 & 7.50 & 38 \\
\hline 15.4 & Conserving mountain ecosystems/biodiversity & 9.17 & 8.33 & 5.00 & 7.50 & 38 \\
\hline $10 . b$ & $\begin{array}{l}\text { Efficient and effective development assistance/financial } \\
\text { flows/direct investment }\end{array}$ & 4.17 & 9.17 & 8.33 & 7.22 & 42 \\
\hline 16.6 & Reduction of bribery/corruption & 9.17 & 4.17 & 8.33 & 7.22 & 42 \\
\hline 17.5 & Global macroeconomic stability & 4.17 & 9.17 & 8.33 & 7.22 & 42 \\
\hline 6.4 & Efficient water use of all sectors & 8.33 & 8.33 & 5.00 & 7.22 & 45 \\
\hline 11.c & Support sustainable construction, local materials) & 8.33 & 9.17 & 4.17 & 7.22 & 45 \\
\hline 15.8 & Prevent invasive species & 8.33 & 8.33 & 5.00 & 7.22 & 45 \\
\hline 1.1 & Eliminate extreme poverty, pay equity & 8.33 & 4.17 & 8.33 & 6.94 & 48 \\
\hline 1.2 & Poverty reduction, pay equity & 8.33 & 4.17 & 8.33 & 6.94 & 48 \\
\hline 1.4 & Enable economic participation for all people & 8.33 & 4.17 & 8.33 & 6.94 & 48 \\
\hline 7.1 & Access affordable, modern energy services & 8.33 & 4.17 & 8.33 & 6.94 & 48 \\
\hline 7.a & Access to research and technology, renewable energy & 4.17 & 8.33 & 8.33 & 6.94 & 48 \\
\hline 7.b & Infrastructure development, modern energy services & 8.33 & 4.17 & 8.33 & 6.94 & 48 \\
\hline 8.2 & $\begin{array}{l}\text { Promote national financial institutions for financial } \\
\text { infrastructure }\end{array}$ & 8.33 & 4.17 & 8.33 & 6.94 & 48 \\
\hline 9.3 & Access financial services SMEs & 4.17 & 8.33 & 8.33 & 6.94 & 48 \\
\hline 11.b & $\begin{array}{c}\text { Urban planning of resource efficiency/mitigation of climate } \\
\text { change }\end{array}$ & 4.17 & 8.33 & 8.33 & 6.94 & 48 \\
\hline 13.a & $\begin{array}{c}\text { Financing of climate protection measures in developing } \\
\text { countries }\end{array}$ & 4.17 & 8.33 & 8.33 & 6.94 & 48 \\
\hline 13.b & $\begin{array}{l}\text { Development of management capacities, climate protection } \\
\text { measures }\end{array}$ & 4.17 & 8.33 & 8.33 & 6.94 & 48 \\
\hline 14.3 & Reduce acidification of the oceans & 4.17 & 8.33 & 8.33 & 6.94 & 48 \\
\hline 14.a & $\begin{array}{l}\text { Scientific cooperation, transfer of marine } \\
\text { technologies/research capacities }\end{array}$ & 4.17 & 8.33 & 8.33 & 6.94 & 48 \\
\hline 14.c & Access small-scale marine resources/markets & 8.33 & 8.33 & 4.17 & 6.94 & 48 \\
\hline 15.3 & Combat desertification, area remediation & 8.33 & 8.33 & 4.17 & 6.94 & 48 \\
\hline 15.6 & Just use/access to benefits of genetic resources & 8.33 & 8.33 & 4.17 & 6.94 & 48 \\
\hline 17.8 & Financial and technical cooperation & 4.17 & 8.33 & 8.33 & 6.94 & 48 \\
\hline 17.12 & Compliance pledges financial assistance & 4.17 & 8.33 & 8.33 & 6.94 & 48 \\
\hline 17.17 & Diffusion of environmentally sound technologies & 8.33 & 4.17 & 8.33 & 6.94 & 48 \\
\hline
\end{tabular}




\section{References}

1. Ramcilovic-Suominen, S.; Pülzl, H. Sustainable development-A 'selling point' of the emerging EU bioeconomy policy framework? J. Clean. Prod. 2018, 172, 4170-4180. [CrossRef]

2. Future Earth. The Contribution of Science in Implementing the Sustainable Development Goals; German Committee Future Earth: Stuttgart, Germany, 2016.

3. Global Bioeconomy Summit. Global Bioeconomy Summit-Conference Report; Office of the Bioeconomy Council: Berlin, Germany, 2018.

4. German Bioeconomy Council. Update Report of National Strategies around the World-Bioeconomy Policy (Part III); Bioeconomy Council: Berlin, Germany, 2018.

5. OECD. Meeting Policy Challenges for a Sustainable Bioeconomy; OECD: Paris, France, 2018.

6. Pfau, S.F.; Hagens, J.E.; Dankbaar, B.; Smits, A.J.M. Visions of Sustainability in Bioeconomy Research. Sustainability 2014, 6, 1222-1249. [CrossRef]

7. McCormick, K.; Kautto, N. The Bioeconomy in Europe: An Overview. Sustainability 2013, 5, 2589-2608. [CrossRef]

8. Bugge, M.; Hansen, T.; Klitkou, A. What Is the Bioeconomy? A Review of the Literature. Sustainability 2016, 8, 691. [CrossRef]

9. Peltomaa, J. Drumming the Barrels of Hope? Bioeconomy Narratives in the Media. Sustainability 2018, 10, 4278. [CrossRef]

10. Kleinschmit, D.; Arts, B.; Giurca, A.; Mustalahti, I.; Sergent, A.; Pulzl, H. Environmental concerns in political bioeconomy discourses. Int. For. Rev. 2017, 19, 41-55. [CrossRef]

11. Bell, J.; Paula, L.; Dodd, T.; Németh, S.; Nanou, C.; Mega, V.; Campos, P. EU ambition to build the world's leading bioeconomy-Uncertain times demand innovative and sustainable solutions. New Biotechnol. 2018, 40 Pt A, 25-30. [CrossRef]

12. Ingrao, C.; Bacenetti, J.; Bezama, A.; Blok, V.; Goglio, P.; Koukios, E.G.; Lindner, M.; Nemecek, T.; Siracusa, V.; Zabaniotou, A.; et al. The potential roles of bio-economy in the transition to equitable, sustainable, post fossil-carbon societies: Findings from this virtual special issue. J. Clean. Prod. 2018, 204, 471-488. [CrossRef]

13. Karliczek, A. Speech on the Occasion of the Global Bioeconomy Summit 2018; German Federal Minister of Education and Research: Berlin, Germany, 2018.

14. Dietz, T.; Börner, J.; Förster, J.J.; Von Braun, J. Governance of the Bioeconomy: A Global Comparative Study of National Bioeconomy Strategies. Sustainability 2018, 10, 3190. [CrossRef]

15. de Besi, M.; McCormick, K. Towards a Bioeconomy in Europe: National, Regional and Industrial Strategies. Sustainability 2015, 7, 10461-10478. [CrossRef]

16. Staffas, L.; Gustavsson, M.; McCormick, K. Strategies and Policies for the Bioeconomy and Bio-Based Economy: An Analysis of Official National Approaches. Sustainability 2013, 5, 2751-2769. [CrossRef]

17. O'Keeffe, S.; Wochele-Marx, S.; Thrän, D. RELCA: A REgional Life Cycle inventory for Assessing bioenergy systems within a region. Energy Sustain. Soc. 2016, 6, 12. [CrossRef]

18. Egea, F.J.; Torrente, R.G.; Aguilar, A. An efficient agro-industrial complex in Almería (Spain): Towards an integrated and sustainable bioeconomy model. New Biotechnol. 2018, 40, 103-112. [CrossRef]

19. Bezama, A.; Siebert, A.; Hildebrandt, J.; Thrän, D. Integration of LCA, LCC, and SLCA methods for assessing a bioeconomy region. In Life Cycle Approaches to Sustainable Regional Development; Routledge: New York, NY, USA, 2017; pp. 258-264.

20. Climate Action Network Europe. Off Target-Ranking of EU Countries' Ambition and Progress in Fighting Climate Change; Climate Action Network Europe: Brussels, Belgium, 2018.

21. Hasenheit, M.; Gerdes, H.; Kiresiewa, Z.; Beekman, V. Summary Report on the Social, Economic and Environmental Impacts of the Bioeconomy. Promoting Stakeholder Engagement and Public Awareness for a Participative Governance of the European Bioeconomy; BioStep: Berlin, Germany, 2016.

22. Siebert, A.; O’Keeffe, S.; Bezama, A.; Zeug, W.; Thrän, D. How not to compare apples and oranges: Generate context-specific performance reference points for a social life cycle assessment model. J. Clean. Prod. 2018, 198, 587-600. [CrossRef]

23. Hildebrandt, J.; Bezama, A.; Thrän, D. Cascade use indicators for selected biopolymers: Are we aiming for the right solutions in the design for recycling of bio-based polymers? Waste Manag. Res. 2017, 35, 367-378. [CrossRef] 
24. Giljum, S.; Bruckner, M.; Gözet, B.; Schutter, L.D. Land under Pressure-Global Impacts of the EU Bioeconomy; Friends of the Earth Europe: Brussels, Belgium, 2016.

25. Budzinski, M.; Bezama, A.; Thran, D. Monitoring the progress towards bioeconomy using multi-regional input-output analysis: The example of wood use in Germany. J. Clean. Prod. 2017, 161, 1-11. [CrossRef]

26. The Bioeconomy Stakeholders Panel. European Bioeconomy Stakeholders Manifesto; European Commission: Brussels, Belgium, 2017.

27. El-Chichakli, B.; von Braun, J.; Lang, C.; Barben, D.; Philp, J. Policy: Five cornerstones of a global bioeconomy. Nature 2016, 535, 221-223. [CrossRef]

28. European Commission. A Sustainable Bioeconomy for Europe: Strengthening the Connection between Economy, Society and the Environment-Updated Bioeconomy Strategy; European Commission: Brussels, Belgium, 2018.

29. Schütte, G. What kind of innovation policy does the bioeconomy need? New Biotechnol. 2018, 40 Pt A, 82-86. [CrossRef]

30. Center for Development Research (ZEF). Bioeconomy as Societal Change. Available online: https://www. bioecon-societal-change.de/ (accessed on 5 July 2018).

31. Wesseler, J.; von Braun, J. Measuring the Bioeconomy: Economics and Policies. Annu. Rev. Resour. Econ. 2017, 9, 275-298. [CrossRef]

32. UN (United Nations) IAEG-SDGs. Available online: https://unstats.un.org/sdgs/iaeg-sdgs/ (accessed on 10 September 2018).

33. Sachs, J.; Schmidt-Traub, G.; Kroll, C.; Durand-Delacre, D.; Teksoz, K. SDG Index and Dashboards Report 2017; Bertelsmann Stiftung and Sustainable Development Solutions Network (SDSN): New York, NY, USA, 2017.

34. Nilsson, M.; Costanza, R. Overall Framework for the Sustainable Development Goals. In Review of Targets for the Sustainable Development Goals: The Science Perspective; International Council for Science (ICSU): Paris, France, 2015; pp. 7-12.

35. Gerdes, H.; Kiresiewa, D.Z.; Beekman, V.; Bianchini, C.; Davies, S.; Griestop, L.; Janssen, R.; Khawaja, C.; Mannhardt, B.; Mazzariol, F.; et al. Engaging Stakeholders and Citizens in the Bioeconomy: Lessons Learned from BioSTEP and Recommendations for Future Research; Ecologic Institute: Berlin, Germany, 2018.

36. UNEP. Towards a Life Cycle Sustainability Assessment-Making Informed Choices on Products; UNEP/SETAC Life Cycle Initiative: Nairobi, Kenya, 2011.

37. Nilsson, M.; Griggs, D.; Visbeck, M. Policy: Map the interactions between Sustainable Development Goals. Nature 2016, 534, 320-322. [CrossRef]

38. Schmidt-Traub, G.; Kroll, C.; Teksoz, K.; Durand-Delacre, D.; Sachs, J.D. National baselines for the Sustainable Development Goals assessed in the SDG Index and Dashboards. Nat. Geosci. 2017, 10, 547-555. [CrossRef]

39. von Braun, J. Bioeconomy-Science and Technology Policy to Harmonize Biologization of Economies with Food Security. In The Fight Against Hunger and Malnutrition: The Role of Food, Agriculture, and Targeted Policies; Sahn, D.E., Ed.; Oxford University Press: Oxford, UK, 2015; pp. 240-262.

40. Council, N.R. Industrialization of Biology: A Roadmap to Accelerate the Advanced Manufacturing of Chemicals; The National Academies Press: Washington, DC, USA, 2015; p. 167.

41. Peplow, M. Industrial biotechs turn greenhouse gas into feedstock opportunity. Nat Biotechnol 2015, 33, 1123-1125. [CrossRef]

42. FAO. The State of World Fisheries and Aquaculture 2016-Contributing to Food Security and Nutrition for All; Food and Agriculture Organization of the United Nations: Rome, Italy, 2016.

43. Lokko, Y.; Heijde, M.; Schebesta, K.; Scholtès, P.; Van Montagu, M.; Giacca, M. Biotechnology and the bioeconomy -Towards inclusive and sustainable industrial development. New Biotechnol. 2018, 40 Pt A, 5-10. [CrossRef]

44. Lubchenco, J.; Barner, A.K.; Cerny-Chipman, E.B.; Reimer, J.N. Sustainability rooted in science. Nat. Geosci. 2015, 8, 741. [CrossRef]

45. Philp, J. The bioeconomy, the challenge of the century for policy makers. New Biotechnol. 2018, 40 Pt A, 11-19. [CrossRef]

46. SDSN (Sustainable Development Solutions Network). An Action Agenda for Sustainable Development; Sustainable Development Solutions Network: Paris, France, 2013.

47. Bezama, A. Understanding the systems that characterise the circular economy and the bioeconomy. Waste Manag. Res. 2018, 36, 553-554. [CrossRef]

48. Beisheim, M.; László Pintér, R.S.C. Monitoring and Review. In Review of Targets for the Sustainable Development Goals: The Science Perspective; International Council for Science (ICSU): Paris, France, 2015; pp. 85-86. 
49. Lu, Y.; Nakicenovic, N.; Visbeck, M.; Stevance, A.S. Policy: Five priorities for the UN Sustainable Development Goals. Nature 2015, 520, 432-433. [CrossRef]

50. BioMonitor. BioMonitor-Monitoring the Bioeconomy. Available online: http://biomonitor.eu/ (accessed on 20 December 2018).

51. Joint Research Centre. BioSAMs for the EU Member States-Constructing Social Accounting Matrices with a Detailed Disaggregation of the Bio-Economy; (European Commission): Brussels, Belgium, 2018.

52. Meijl, H.V. Design of a Systems Analysis Tools Framework for the EU Bio-Based Economy Strategy (SAT-BBE); LEI Wageningen UR: Hague, The Netherlands, 2015.

53. SYMOBIO. Systematic Monitoring and Modeling of the Bioeconomy. Available online: https://symobio.de/ en/start_en (accessed on 5 January 2018).

54. Egenolf, V.; Bringezu, S. Conceptualization of an Indicator System for Assessing the Sustainability of the Bioeconomy. Sustainability 2019, 11, 443. [CrossRef]

55. Kircher, M.; Breves, R.; Taden, A.; Herzberg, D. How to capture the bioeconomy's industrial and regional potential through professional cluster management. New Biotechnol. 2018, 40 Pt A, 119-128. [CrossRef]

56. Funtowicz, S.O.; Ravetz, J.R. Uncertainty and Quality in Science for Policy; Springer Science \& Business Media: Berlin, Germany, 1990; Volume 15.

57. Martinez-Alier, J.; Munda, G.; O'Neill, J. Weak comparability of values as a foundation for ecological economics. Ecol. Econ. 1998, 26, 277-286. [CrossRef]

58. Munda, G. Social Multi-Criteria Evaluation for a Sustainable Economy; Springer: Berlin, Germany, 2008.

59. Garmendia, E.; Gamboa, G. Weighting social preferences in participatory multi-criteria evaluations: A case study on sustainable natural resource management. Ecol. Econ. 2012, 84, 110-120. [CrossRef]

60. O'Neill, J. Representing people, representing nature, representing the world. Environ. Plan. C 2001, 19, 483-500. [CrossRef]

61. European Commission. Innovating for Sustainable Growth: A Bioeconomy for Europe; European Commission: Brussels, Belgium, 2012.

62. Dupont-Inglis, J.; Borg, A. Destination bioeconomy-The path towards a smarter, more sustainable future. New Biotechnol. 2018, 40 Pt A, 140-143. [CrossRef]

63. Małyska, A.; Jacobi, J. Plant breeding as the cornerstone of a sustainable bioeconomy. New Biotechnol. 2018, 40 Pt A, 129-132. [CrossRef]

64. Civil Society Action-Forum on Bioeconomy Declaration of German Environmental and Development Organizations on the Bioeconomy Policy of the Federal Government of Germany. Available online: https: / / denkhausbremen.de/wp-content/uploads /2019/02/German-ENGO-Bioeconomy-declaration-.pdf (accessed on 16 January 2019).

65. European Commission. Bio-Based Economy for Europe: State of Play and Future Potential Part 1; European Commission: Brussels, Belgium, 2011.

66. Sisto, R.; van Vliet, M.; Prosperi, M. Puzzling stakeholder views for long-term planning in the bio-economy: A back-casting application. Futures 2016, 76, 42-54. [CrossRef]

67. Hausknost, D.; Schriefl, E.; Lauk, C.; Kalt, G. A Transition to Which Bioeconomy? An Exploration of Diverging Techno-Political Choices. Sustainability 2017, 9, 669. [CrossRef]

68. Future Earth Knowledge-Action Networks. Available online: http:/ / futureearth.org/knowledge-actionnetworks (accessed on 1 November 2018).

69. Kanter, D.R.; Schwoob, M.H.; Baethgen, W.E.; Bervejillo, J.E.; Carriquiry, M.; Dobermann, A.; Ferraro, B.; Lanfranco, B.; Mondelli, M.; Penengo, C.; et al. Translating the Sustainable Development Goals into action: A participatory backcasting approach for developing national agricultural transformation pathways. Glob. Food Secur. Agric. 2016, 10, 71-79. [CrossRef]

70. TFM (10-Member Group to support Technology Facilitation Mechanism). Harnessing the Contribution of Science, Technology, and Innovation for achieving the 2030 Agenda and the 17 Sustainable Development Goals. Available online: https://sustainabledevelopment.un.org/content/documents/ 21201STI\%20for\%20SDGs\%2010\%20member\%20group\%20STI\%20Forum\%20final\%20clean.pdf (accessed on 5 November 2018).

71. Weaver, P.M.; Rotmans, J. Integrated sustainability assessment: What is it, why do it and how? Int. J. Innov. Sustain. Dev. 2006, 1, 284-303. [CrossRef] 
72. Munda, G. Social multi-criteria evaluation: Methodological foundations and operational consequences. Eur. J. Oper. Res. 2004, 158, 662-677. [CrossRef]

73. Munda, G. Multiple Criteria Decision Analysis and Sustainable Development. In Multiple Criteria Decision Analysis: State of the Art Surveys; Springer: New York, NY, USA, 2005; pp. 953-986.

74. Banville, C.; Landry, M.; Martel, J.-M.; Boulaire, C. A stakeholder approach to MCDA. Syst. Res. Behav. Sci. 1998, 15, 15-32. [CrossRef]

75. UNEP. Major Groups \& Stakeholders. Available online: https://www.unenvironment.org/civil-societyengagement/why-civil-society-matters/major-groups-stakeholders (accessed on 28 November 2018).

76. Dryzek, J. Deliberative Democracy and Beyond: Liberals, Critics, Contestations; Oxford University Press: Oxford, UK, 2002.

77. Habermas, J. Between Facts and Norms: Contributions to a Discourse Theory of Law and Democracy; MIT Press: Cambridge, MA, USA, 1996.

78. Podinovskii, V.V. Criteria importance theory. Math. Soc. Sci. 1994, 27, 237-252. [CrossRef]

79. Roberts, F.S. Measurement Theory: With Applications to Decision Making Utility and the Social Sciences; Addison-Wesley Advanced Book Program: London, UK, 1979.

80. Vincke, P. Multicriteria Decision-Aid; Wiley: New York, NY, USA, 1992.

81. Sen, A. Rationality and Social Choice. Am. Econ. Rev. 1995, 85, 1-24.

82. Chiranjeevi, P.; Dahiya, S.; Kumar, N. Waste derived bioeconomy in India: A perspective. New Biotechnol. 2018, 40 Pt A, 60-69.

83. Sanchez Rodriguez, R.; Ürge-Vorsatz, D.; Barau, A.S. Sustainable Development Goals and climate change adaptation in cities. Nat. Clim. Chang. 2018, 8, 181-183. [CrossRef]

84. Rosillo-Calle, F. Food versus Fuel-An Informed Introduction to Biofuels; ZED Books: London, UK, 2010.

85. Mohr, A.; Raman, S. Lessons from first generation biofuels and implications for the sustainability appraisal of second generation biofuels. Energy Policy 2013, 63, 114-122. [CrossRef]

86. Coase, R. The Conduct of Economics: The Example of Fisher Body and General Motors. J. Econ. Manag. Strategy 2006, 15, 255-278. [CrossRef]

87. Thaler, R.H. Misbehaving; W.W. Norton \& Company: New York, NY, USA, 2015.

88. Farnsworth, W. Do Parties to Nuisance Cases Bargain after Judgment? A Glimpse inside the Cathedral. Univ. Chic. Law Rev. 1999, 66, 373-436. [CrossRef]

89. Kates, R.W.; Parris, T.M.; Leiserowitz, A.A. What is Sustainable Development? Goals, Indicators, Values, and Practice. Environ. Sci. Policy Sustain. Dev. 2005, 47, 8-21.

90. Mebratu, D. Sustainability and sustainable development: Historical and conceptual review. Environ. Impact Assess. Rev. 1998, 18, 493-520. [CrossRef]

91. Hopwood, B.; Mellor, M.; O’Brien, G. Sustainable development: Mapping different approaches. Sustain. Dev. 2005, 13, 38-52. [CrossRef]

92. Spaiser, V.; Ranganathan, S.; Swain, R.B.; Sumpter, D.J.T. The sustainable development oxymoron: Quantifying and modelling the incompatibility of sustainable development goals. Int. J. Sustain. Dev. World Ecol. 2017, 24, 457-470. [CrossRef]

93. Nerini, F.; Tomei, J.; Seng To, L.; Bisaga, I.; Parikh, P.; Black, M.; Borrion, A.; Spataru, C.; Castán Broto, V.; Anandarajah, G.; et al. Mapping Synergies and Trade-Offs between Energy and the Sustainable Development Goals. Nat. Energy 2018, 3, 10. [CrossRef]

94. Becker, E.; Hummel, D.; Jahn, T. Societal relations to nature as a common frame of reference for integrated environmental research. Available online: https:/ /www.researchgate.net/profile/Egon_Becker/ publication/258134131_becker-hummel-jahn-soc-rel-nat-en-2012/links / Odeec5271851882bb4000000/ becker-hummel-jahn-soc-rel-nat-en-2012.pdf (accessed on 11 March 2019).

95. Görg, C. The construction of societal relationships with nature. Poiesis \& Praxis 2004, 3, 22-36.

96. Meadowcroft, J. What about the politics? Sustainable development, transition management, and long term energy transitions. Policy Sci. 2009, 42, 323. [CrossRef]

(C) 2019 by the authors. Licensee MDPI, Basel, Switzerland. This article is an open access article distributed under the terms and conditions of the Creative Commons Attribution (CC BY) license (http:/ / creativecommons.org/licenses/by/4.0/). 